\title{
Systems Engineering Product Breakdown Structure for the Hanford Cleanup Mission: First Issue
}

\section{J. J. Holmes}

K. B. Bailey

Westinghouse Hanford Company

\section{J. L. Collings}

A. B. Hubbard

T. M. Niepke

Science Applications International Corporation

Date Published

August 1994

Prepared for the U.S. Department of Energy Office of Environmental Restoration and Waste Management

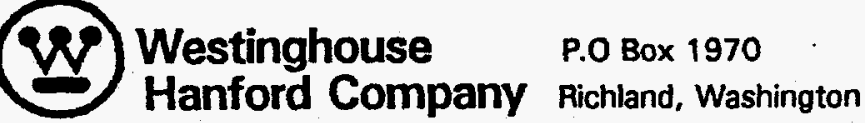

Hanford Operations and Engineering Contractor for the

U.S. Department of Energy under Contract DE-AC06-87RL10930 


\section{DISCLAIMER}

This report was prepared as an account of work sponsored by an agency of the United States Government. Neither the United States Government nor any agency thereof, nor any of their employees, make any warranty, express or implied, or assumes any legal liability or responsibility for the accuracy, completeness, or usefulness of any information, apparatus, product, or process disclosed, or represents that its use would not infringe privately owned rights. Reference herein to any specific commercial product, process, or service by trade name, trademark, manufacturer, or otherwise does not necessarily constitute or imply its endorsement, recommendation, or favoring by the United States Government or any agency thereof. The views and opinions of authors expressed herein do not necessarily state or reflect those of the United States Government or any agency thereof. 


\section{DISCLAIMER}

Portions of this document may be illegible in electronic image products. Images are produced from the best available original document. 


\section{RELEASE AUTHORIZATION}

Document Number: WHC-EP-0801 Draft

Document Title: Systems Engineering Product Breakdown Structure for the Hanford Cleanup Mission: First Issue

Release Date: $\quad 8 / 26 / 94$

***************

This document was reviewed following the procedures described in WHC-CM-3-4 and is:

APPROVED FOR PUBLIC RELEASE

**************

WHC Information Release Administration Specialist:

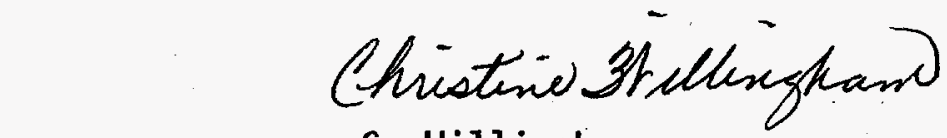

C. Willingham

$8 / 26 / 94$

(Signature)

(Date) 


\section{WHC-EP-0801 DRAFT}

This page left intentionally blank. 


\title{
SYSTEMS ENGINEERING PRODUCT BREAKDOWN STRUCTURE
} FOR THE HANFORD CLEANUP MISSION: FIRST ISSUE

\author{
J. J. Holmes \\ K. B. Bailey \\ J. L. Collings \\ A. B. Hubbard \\ T. M. Niepke
}

\begin{abstract}
SUMMARY
This document provides the product breakdown structure (PBS) for the upper level physical products that, when delivered, complete the Hanford Site Cleanup Mission. Development of the PBS is a continuation of the sitewide systems engineering work described in the sitewide functional analysis (Ref. 1), the architecture synthesis (Ref. 2), and the product description report (Ref. 3) and is generally consistent with guidance contained in the Hanford Mission Plan (Ref. 4). The PBS presents the interrelationship of products produced by the functions that are necessary to perform the clean up mission from their initial source through interim products to final product disposition.
\end{abstract}

The PBS is directly derived from the referenced documents and presents the products resulting from the cleanup mission in a hierarchical format. As in the case of the preceding documents, no attempt has been made to integrate the products into an optimum set. Optimization of the product set and product breakdown structure will require analysis of the "raw" products for the following purposes.

- Reveal opportunities to satisfy several functions with one product.

- Eliminate overlap.

- Fill in gaps.

Once the optimization targets are identified, the functional analysis and architectural synthesis will be revisited and updated to reflect the improvement opportunities. The whole process will need to be repeated a 
number of times to become internally consistent. It should be noted that the architectural synthesis has yet to be analyzed in detail for cost, risk, regulatory, and public acceptance issues and must be subjected to all appropriate regulatory approval processes and validation by the U. S. Department of Energy (DOE) before it can be adopted as the technical basis for the Hanford Cleanup Mission. Because of this, the product breakdown structure provided here must be considered only as reflecting the initial identification of products and their relationship to the site mission.

This document is organized as follows:

- Section 1.0 provides the PBS graphically showing the hierarchical relationship of the various products, subproducts, and interim products. Because the overall PBS is too large to be presented in a single figure, the structure has been logically separated into related products and presented in Figure 1-1 through 1-24. Figure 1-1 provides the top-level PBS and an index to the remaining figures.

- Section 2.0 describes the products presented in the PBS.

Information provided in this report emphasizes the physical outputs of the system functions associated with Function 4, Remedy Unsafe and Unacceptable Conditions and Function 5, Transition Resources for Beneficial Use. All subfunctions of Function 4 are included down to level 4 (4.X.X.X) with the exception of Function 4.6, Correct Unsafe Infrastructure Conditions. Additional work is required to integrate Function 4.6 work with the sitewide system.

As a result of the activity associated with developing the product description report (Ref. 3), the names of some of the outputs of functions depicted in the Integrated Definition Language Notation (IDEFO) diagrams contained in the functional analysis (Ref. 1) were decomposed to lend the required physical attributes to the function outputs and to better support the development of a product breakdown structure. An example of this 
decomposition is the conversion of the "Dispositioned Legacy" product contained in the functional analysis documentation (Ref. 1) into "Released Effluents," "Waste/Materials Dispositioned Offsite," and "Waste/Materials Dispositioned Onsite." In these cases, the decompositions also will be reflected when the second issue of the functional analysis is published. Also, some specific function outputs were determined to be missing from the functional analysis (Ref. 1) and have been added as products in Section 1.0 of this report.

Consistency with previous reports has been maintained utilizing the RDD-100 tool.

The next step in the sitewide systems engineering analysis work is to examine the functional analysis for areas of overlap or omission and to optimize the system. The functional analysis will then be updated and the resulting initial technical baseline will be documented through the development of detailed product/process functional specifications.

RDD-100 is a trademark of Ascent Logic Corporation. 
WHC-EP-0801 DRAFT

This page left intentionally blank. 


\section{CONTENTS}

1.0 PRODUCT BREAKDOWN STRUCTURE ............... . . . 1-1

2.0 PRODUCT DESCRIPTIONS ....................... 2-1

3.0 REFERENCES .......................... 3-1

LIST OF FIGURES

1-1 Clean Up Hanford .................... 1-3

1-2 Transferable Resources from Deactivation ......... 1-4

1-3 Transferable Resources from Deactivation (Type 1) . . . . . 1-5

1-4 Transferable Resources from Deactivation (Type 2) . . . . 1-6

1-5 Transferable Resources from Deactivation (Type 3) ...... 1-7

1-6 Transferable Resources from Deactivation (Type 4) ..... 1-8

1-7 Transferable Resources from Tank Waste Remediation ..... 1-9

1-8 Transferable Resources from Remedy/Restore ......... 1-10

1-9 Transferable Resources from Aqueous Waste . . . . . . . 1-11

1-10 Transferable Resources from SNM/NM/NF Cleanup . . . . . . 1-12

1-11 LLW/LLMW . . . . . . . . . . . . . . . . 1-13

1-12 Treated Effluent and Documentation .......... 1-14

1-13 Untreated Effluent and Documentation .......... 1-15

1-14 Closed Waste Disposal Facility ............. 1-16

1-15 Closed ILLW Sites ................ 1-17

1-16 Waste to Storage ............... 1-18

1-17 Hazardous Waste ................ 1-19

1-18 Deactivated Facilities .............. 1-20

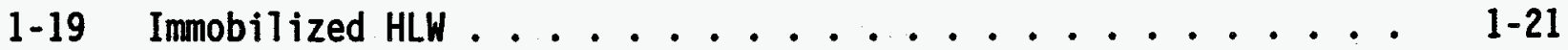

1-20 overpacked Capsules ... . . . . . . . . . . 1-22

1-21 Immobilized TRU Waste ................ 1-23

1-22 Processed Post-70 TRU/TRUM ............. 1-. 1-24

1-23 SNM/NM/NF Dispositioned Offsite ........... 1-25

1-24 Released Effluents .............. 1-26

\section{LIST OF TABLES}

2-1 Product Descriptions ............... 2-2 
WHC-EP-0801 DRAFT

\section{LIST OF TERMS}

DOE

U.S. Department of Energy

IDEFO Integrated Definition Language Notation

PBS

Product Breakdown Structure 


\subsection{PRODUCT BREAKDOWN STRUCTURE}

Figures 1-1 through 1-24 present the product breakdown structure (PBS) for the upper level physical products that, when delivered, complete the Hanford Cleanup Mission. These figures show the hierarchical relationship of the various products, subproducts, and interim products. Figure 1-1 provides the top level PBS. Each lowest level product box contained the number of a figure number identifies the lower level product breakdown structure. For example, the eighth box from the left, LLW/LLMW, contains the reference to Figure 1-11. Figure 1-7 is the PBS for LLW/LLMW.

The site level PBS was generated manually from the data contained in the RDD-100 tool, but only to level 4 of the functional analysis. This is consistent with the product description report (Ref. 3 ). Therefore, this product structure has not taken advantage of decompositions below level 4 of the functions and products in the RDD-100 tool. The RDD-100 tool is being improved to provide the capability to generate product structures at any level using the full data set (lowest level decomposition). It is anticipated that this capability will be in place in time to support the final version of this PBS.

Most of the products in the PBS have associated numbers enclosed in brackets. These numbers indicate the function from the functional analysis (Ref. 1) that produces the product. A number such as "4.3.1.a11" indicate that all next lower level functions to 4.3.1 produce the product. Products without an associated function have yet to be properly tunneled, that is associated with (or connected to) other functions within the functional analysis.

It should be noted that all lowest level products in Figure 1-1 do not have an applicable lower level product breakdown structure. This is true for Transferable Waste from Solid Waste, Transferable Resources from Infrastructure, RCRA Covered Trench, Sanitary Sewage, Landfill Wastes, and Sanitary Landfill Waste. These products either have no applicable lower level 
products, as in the case of a byproduct resulting from performing a function, or no lower level product structure exists because the functional decomposition is incomplete.

- Refinement of the functional analysis will result in a further decomposition of the system functions and products and will be used in the generation of the final version of the PBS. 



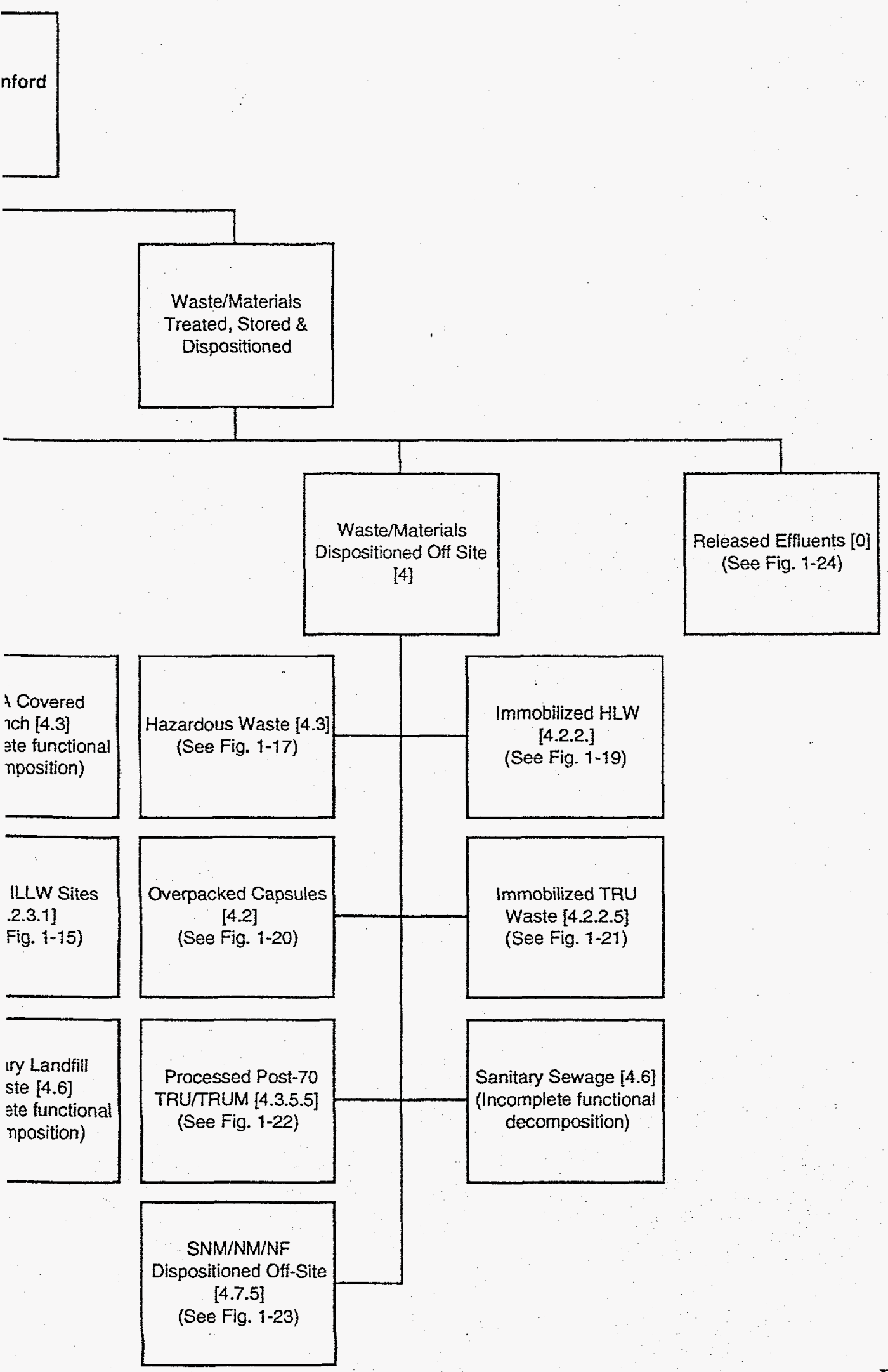

Figure 1-1. Clean Up Hanford 


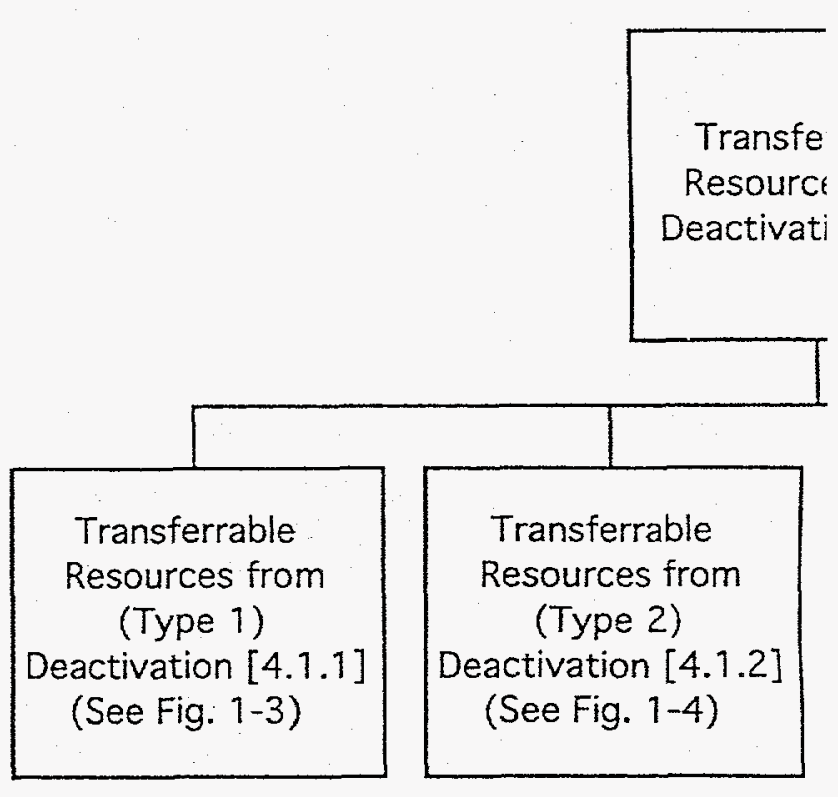


WHC-EP-0801 DRAFT

ble

from

[4.1]

\begin{tabular}{|c|c|}
\hline $\begin{array}{c}\text { Transferrable } \\
\text { Resources from } \\
\text { (Type 3) } \\
\text { leactivation [4.1.3] } \\
\text { (See Fig. 1-5) }\end{array}$ & $\begin{array}{c}\text { Transferrable } \\
\text { Resources from } \\
\text { (Type } 4 \text { ) } \\
\text { Deactivation }[4.1 .4] \\
\text { (See Fig. } 1-6 \text { ) }\end{array}$ \\
\hline
\end{tabular}

Figure 1-2. Transferable Resources from Deactivation $1-4$ 


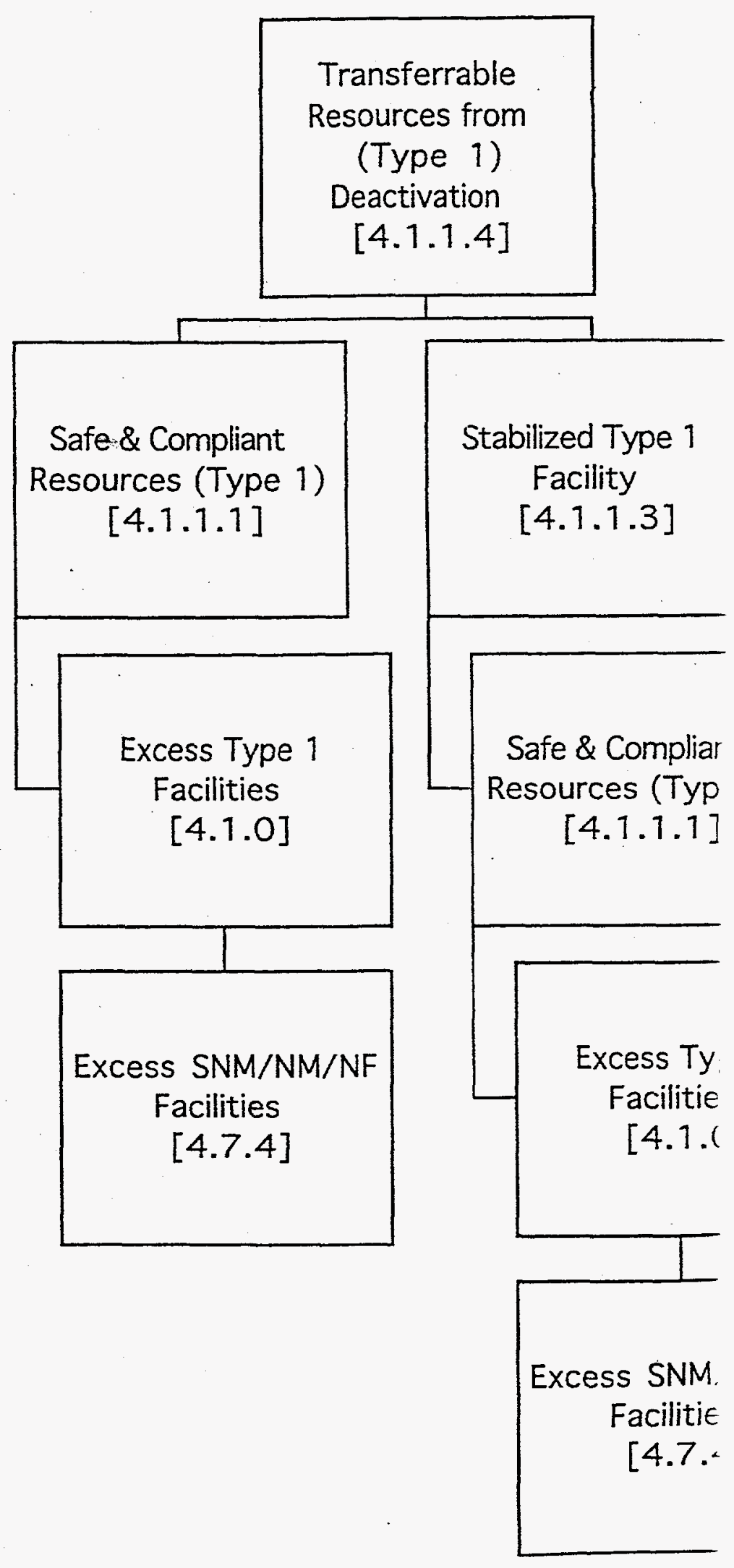




le
om
)
$n$
$b]$

zabilized Type 1

Facility

$[4.1 .1 .3]$

Safe \& Compliant Resources (Type 1)

[4.1.1.1]

Excess Type 1

Facilities

[4.1.0]

Excess SNM/NM/NF

Facilities

[4.7.4] 
Transferable

Resources from

(Type 2)

Deactivation

[4.1.2.3]

afe \& Compliant Resources (Type 2

[4.1.2.1]

Facilities [4.1.0]
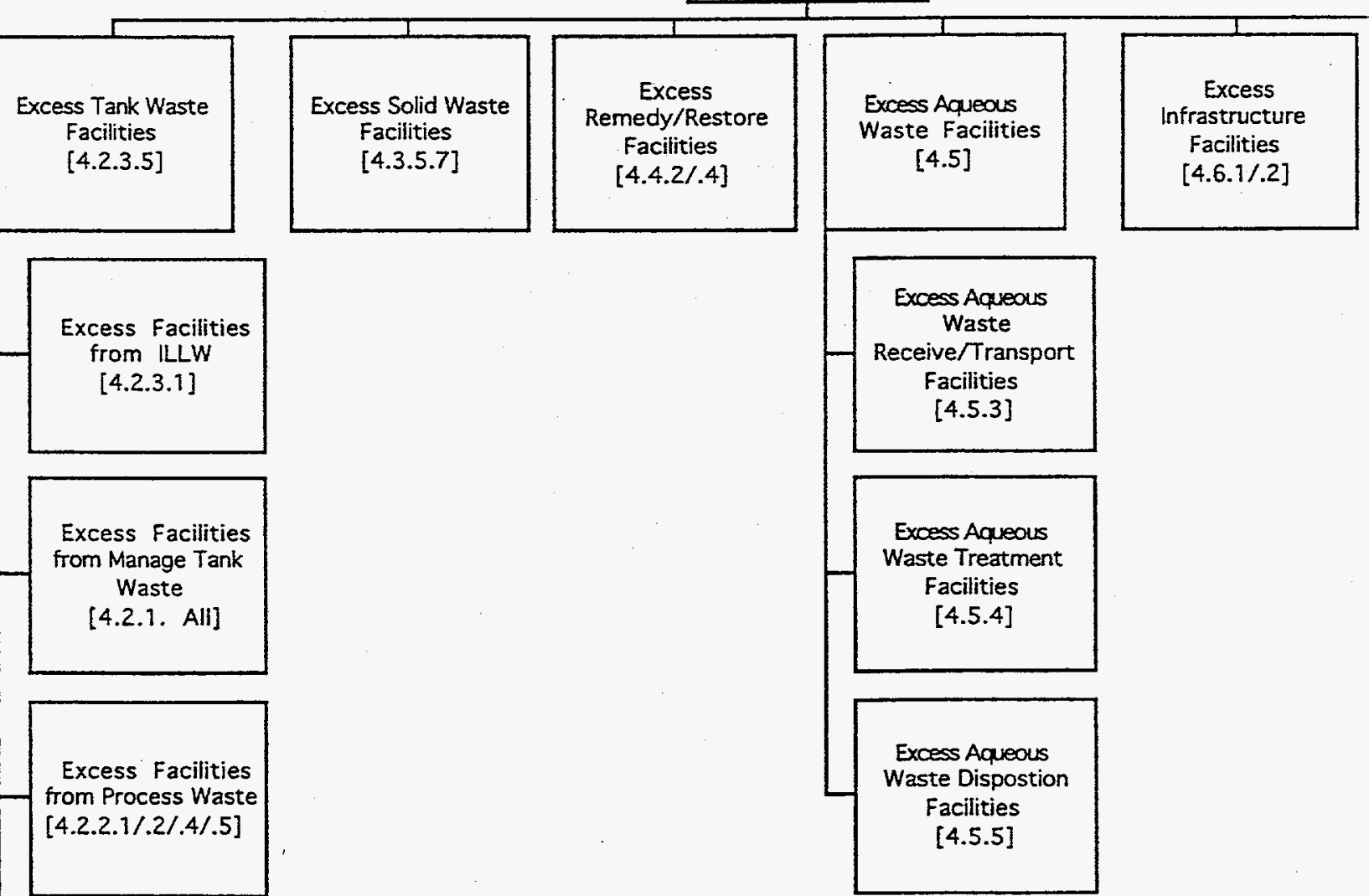

Facilities

[4.3.5.7]
[4.5]

Excess Aqueous

Waste Treatment

Facilities

[4.5.4]

Excess Aqueous

Waste Dispostion

Facilities

[4.5.5]

Excess Facilities from Disposition Reusable Materials [4.2.3.6] 


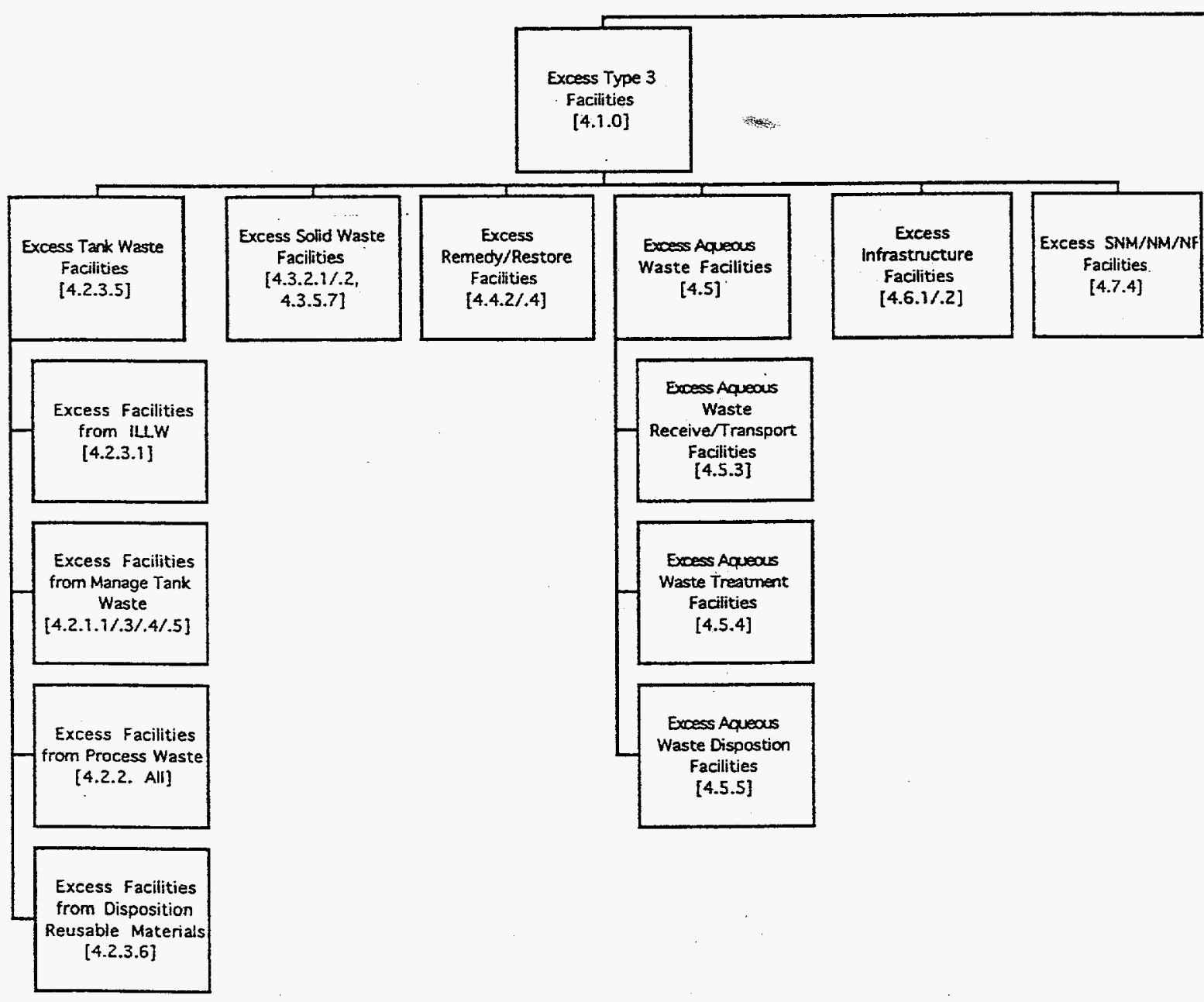

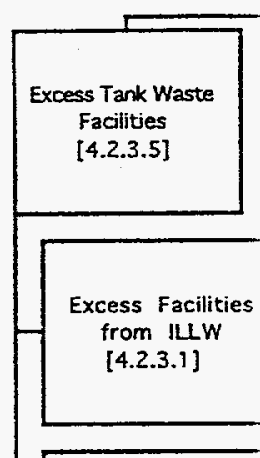

Excess Facilities from Manage Tank Waste

[4.2.1.1/.3/.4/.5]

Excess Facilities from Process Wast

[4.2.2. All]

xcess Facilities from Disposition Reusable Material [4.2.3.6] 


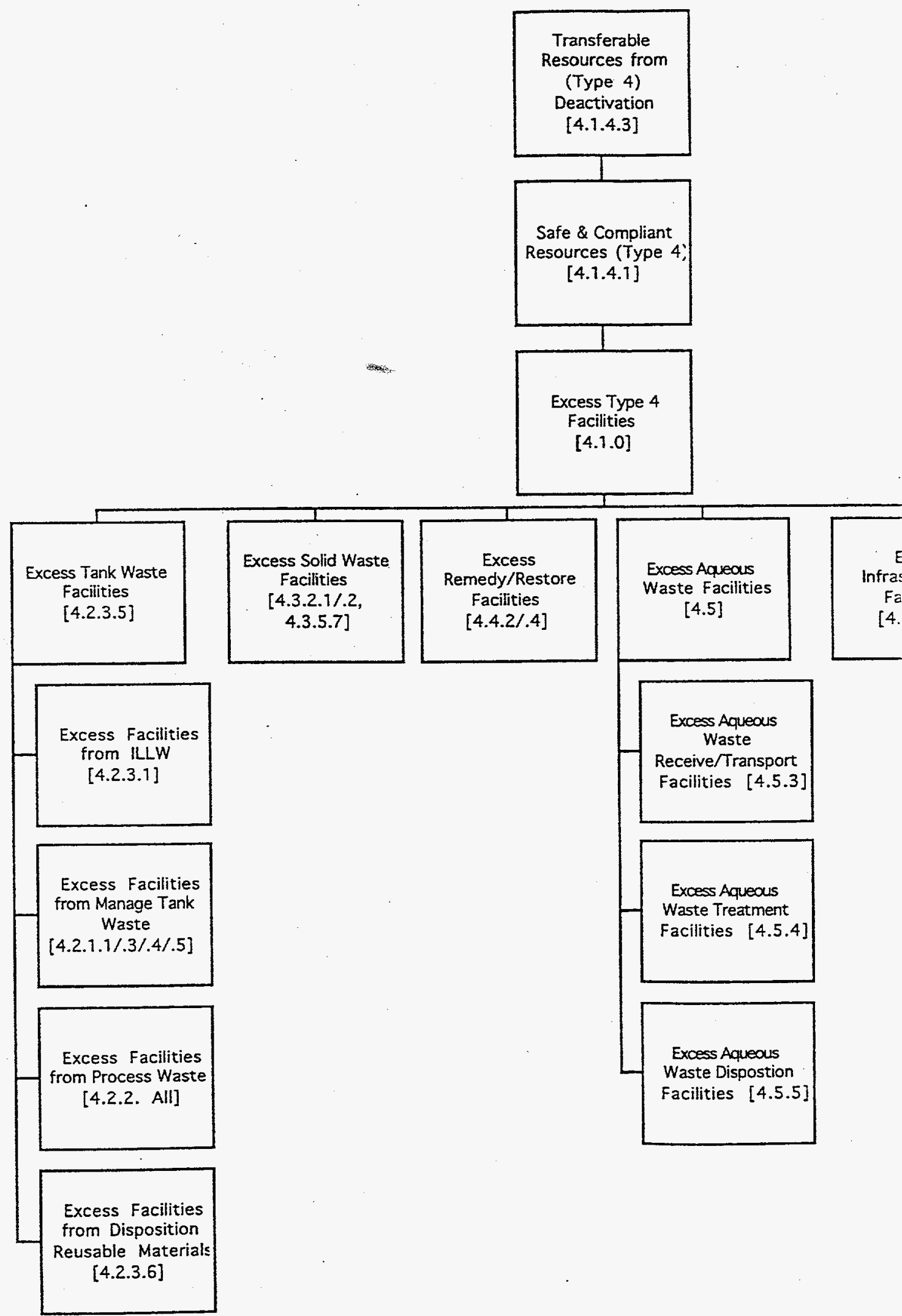


insferable surces from

Type 4)

activation

4.1.4.3]

1

\& Compliant rces (Type 4; 4.1.4.1]

\section{7}

ess Type 4

acilities

[4.1.0]

Excess Aqueous

Waste Facilities

[4.5]

Excess

Infrastructure

Facilities

[4.6.1/.2]
Excess SNM/NM/NF

Facilities

[4.7.3/.4]

Excess Aqueous

Waste Treatment

Facilities [4.5.4]

$$
\text { Waste }
$$

Receive/Transport

Facilities [4.5.3]

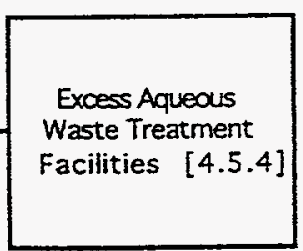

Excess Aqueous

Waste Dispostion

Facilities [4.5.5]

Figure 1-6. Transferable Resources from Deactivation (Type 4) 

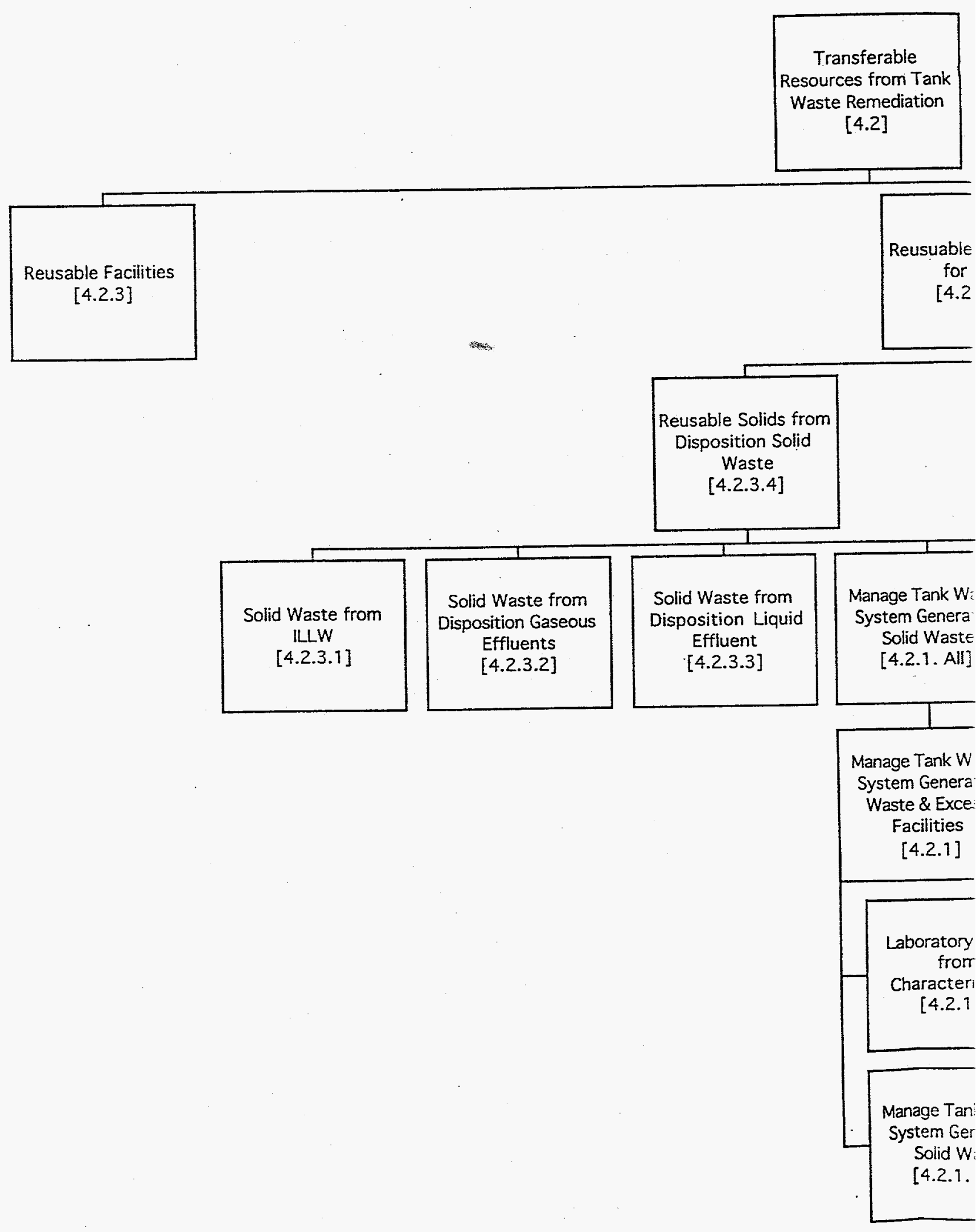
insferable es from Tank

Remediation

[4.2]

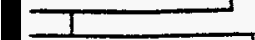

Reusuable Materials for Site [4.2.3.6]

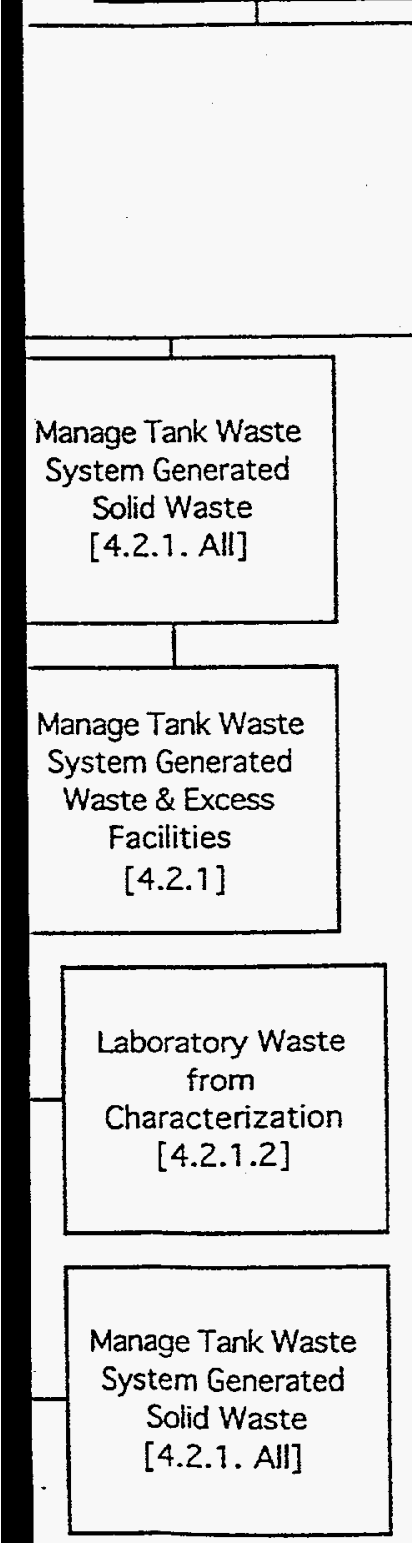

Process Waste System Generated

Solid Waste

[4.2.2. All]

Process Waste System Generated Waste \& Excess

Facilities [4.2.2]

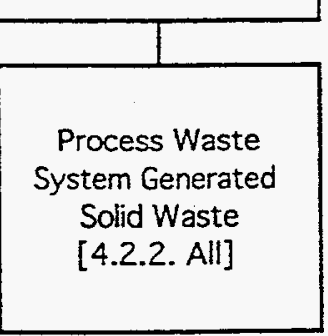

放数 $=$

Reusable Liquid from Disposition Liquid Effluent [4.2.3.3]

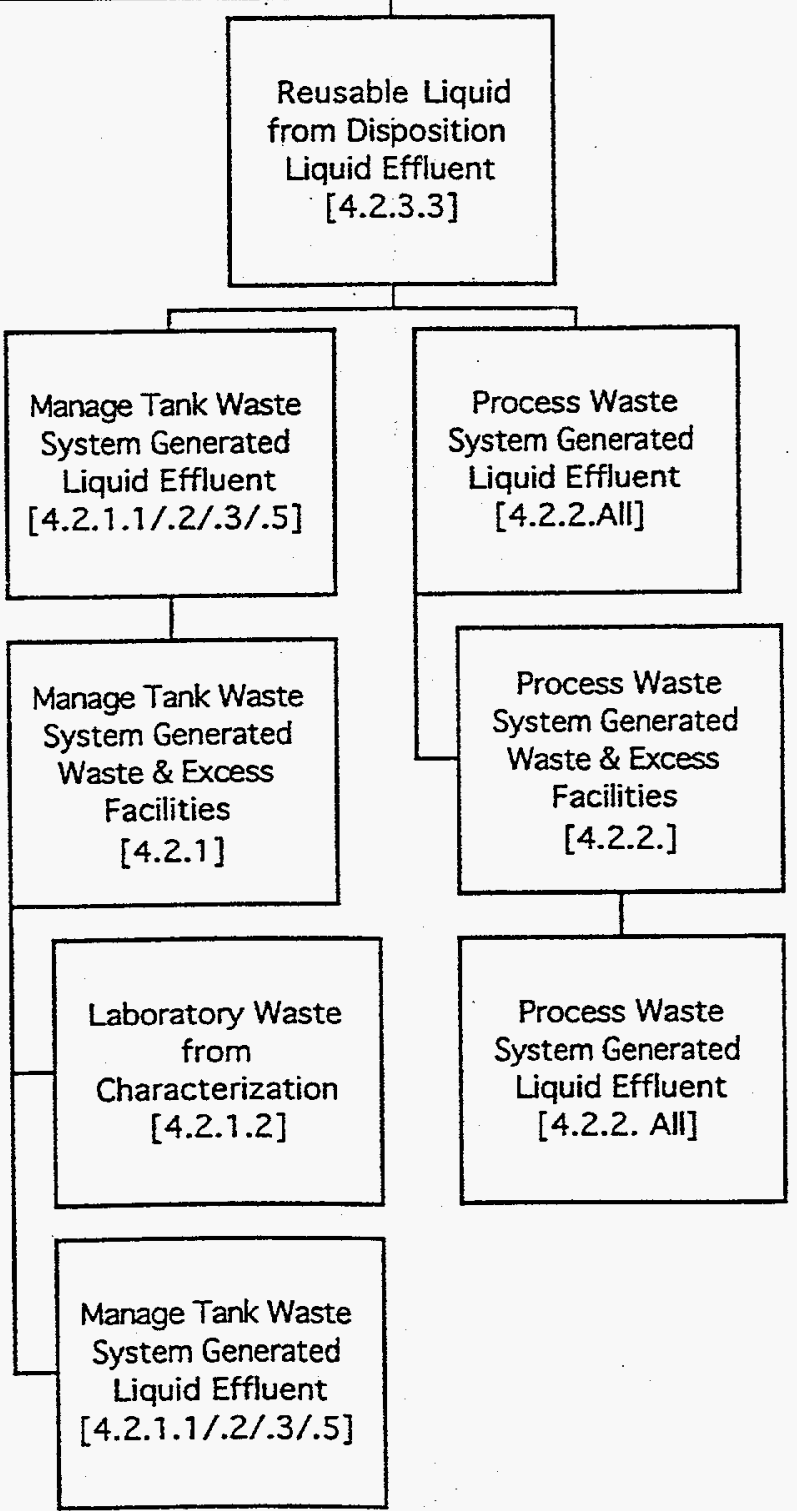

Figure 1-7. Transferable Resources from Tank Waste Remediation 


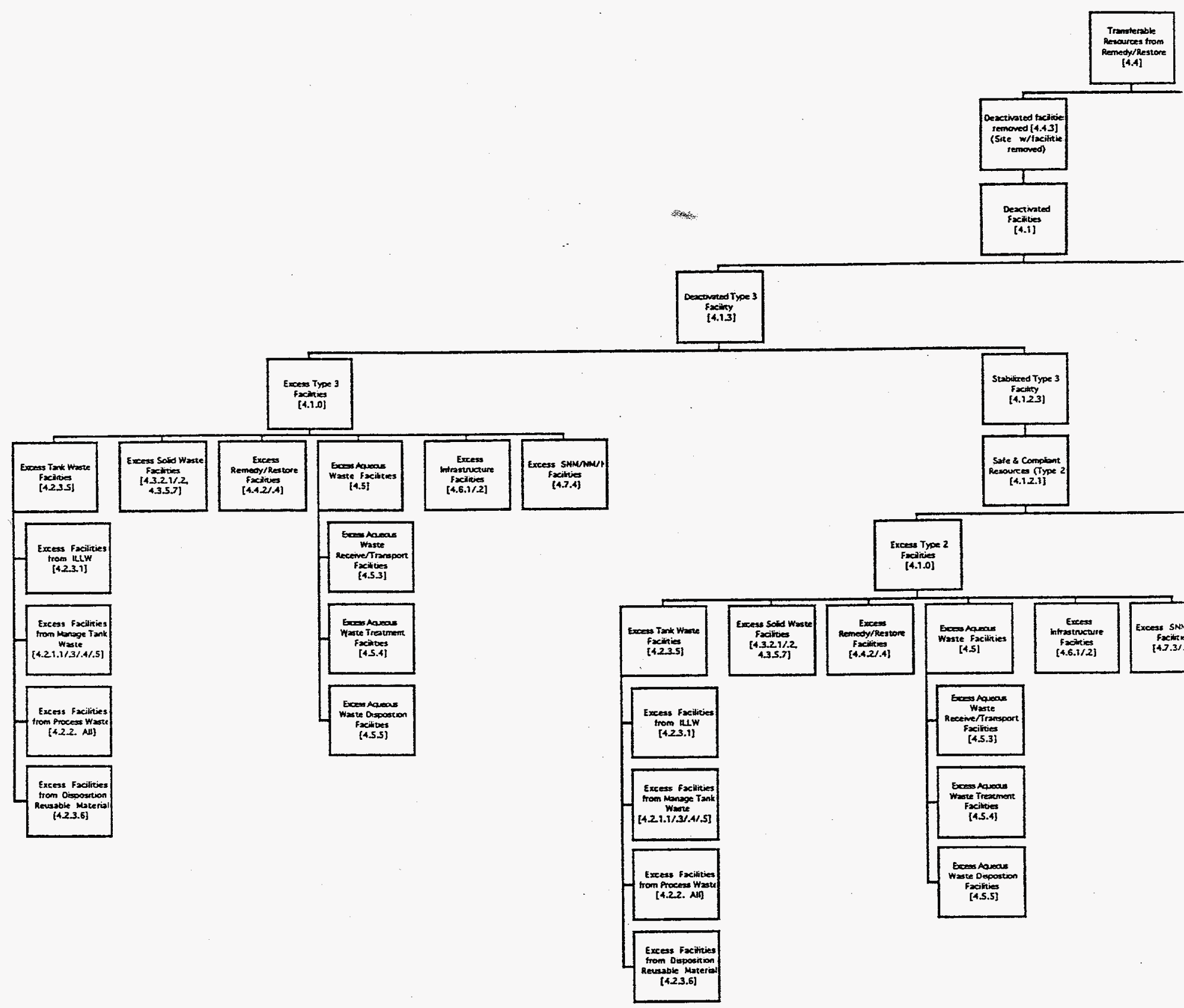




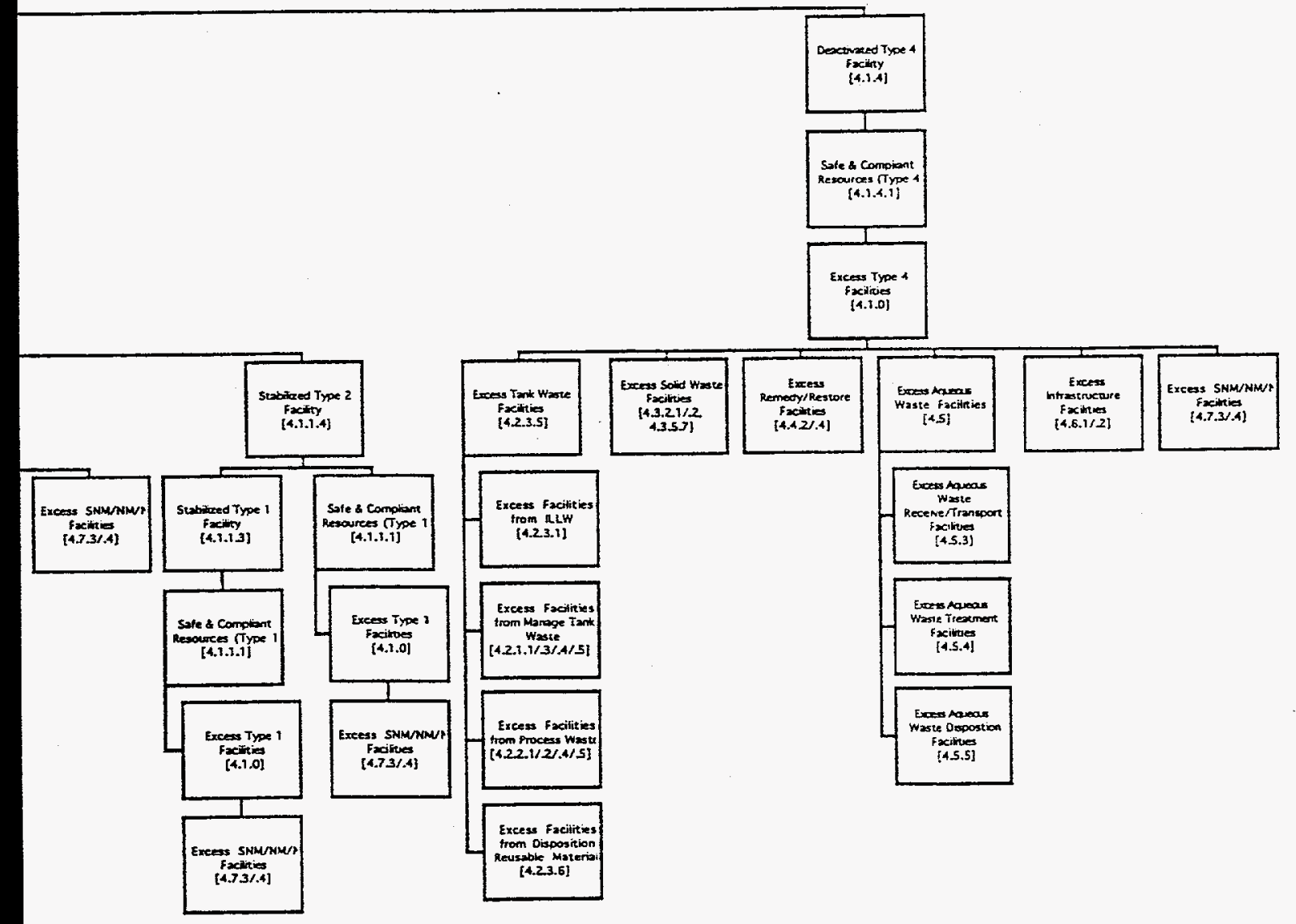

Figure 1-8. Transferable Resources from Remedy/Restore 


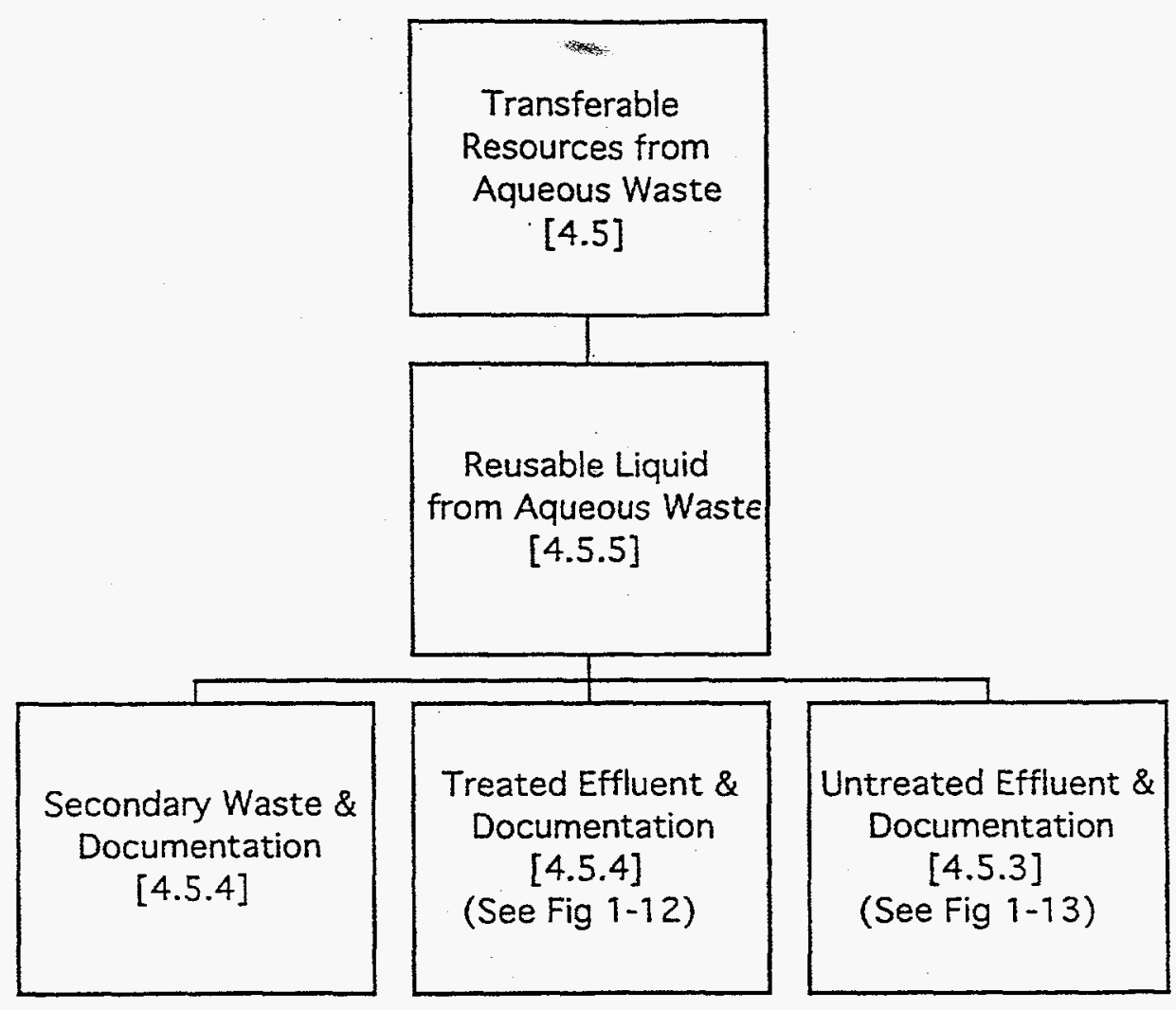


WHC-EP-0801 DRAFT

ible

from

Waste

us Waste

i]

\begin{tabular}{l}
\hline fluent \& \\
tation \\
t] \\
$-12)$
\end{tabular}$\quad\left[\begin{array}{c}\text { Untreated Effluent \& } \\
\text { Documentation } \\
\text { (See Fig 1-13) }\end{array}\right.$

Figure 1-9. Transferable Resources from Aquenus Waste 


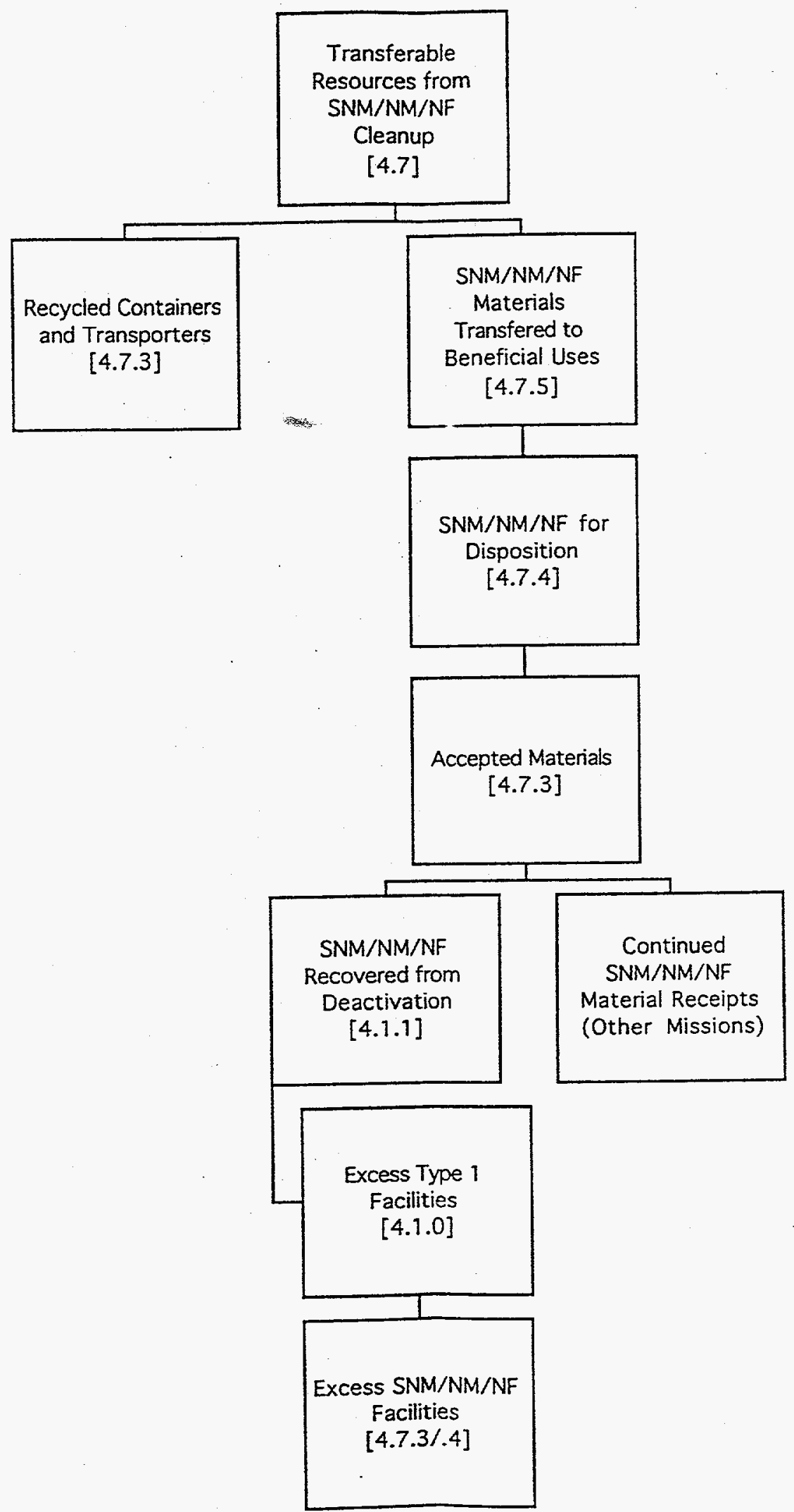


sle

rom

NF

,

SNM/NM/NF

Materials

Transfered to

Beneficial Uses

[4.7.5]

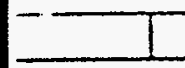

SNM/NM/NF for

Disposition

[4.7.4]

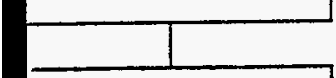

Accepted Materials

[4.7.3]

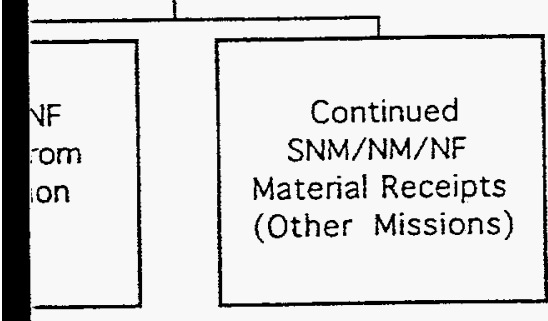

ype 1

ries

.0]

sess

$\because$

Figure 1-10. Transferable Resources from SNM/NM/NF Cleanup 


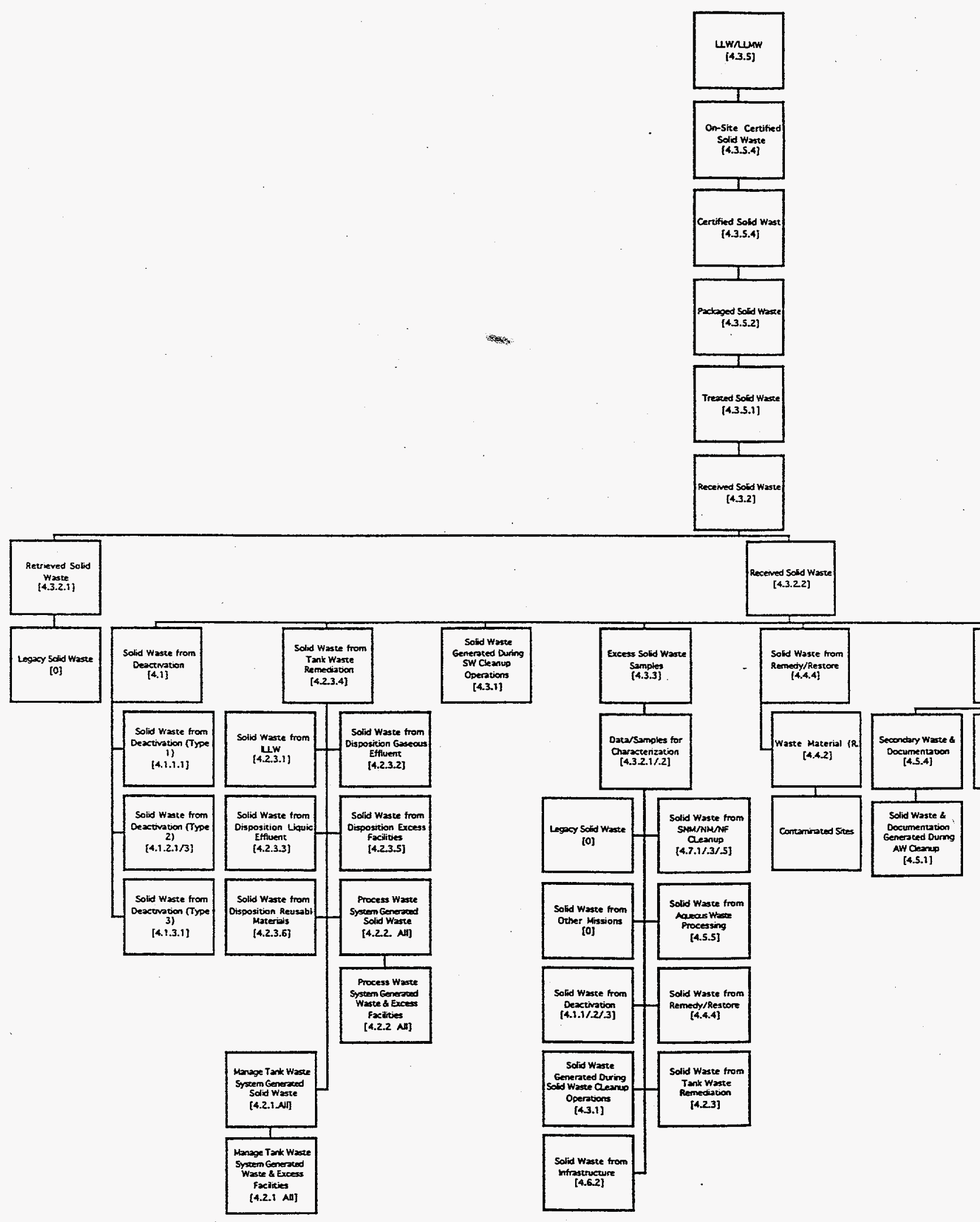




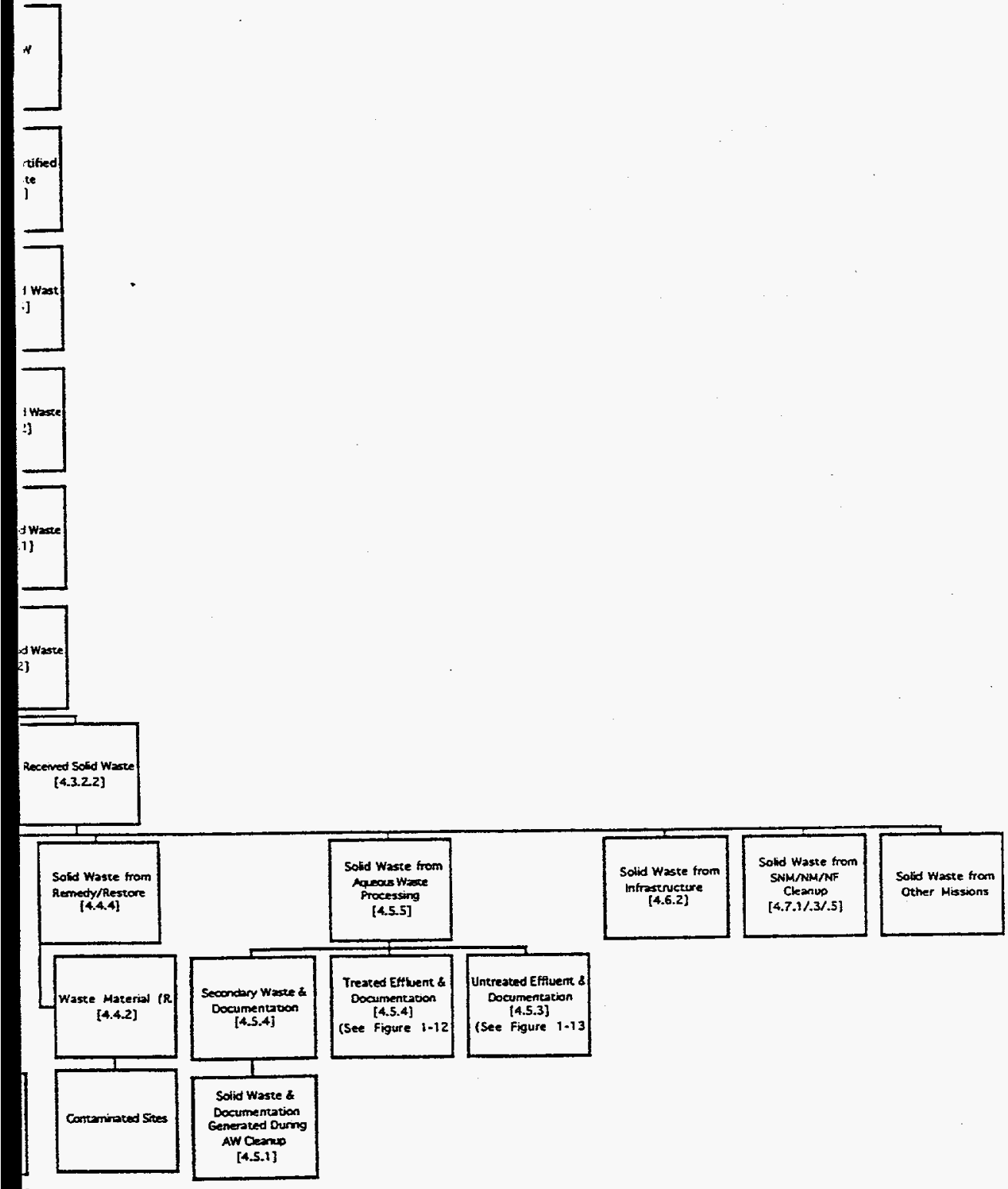




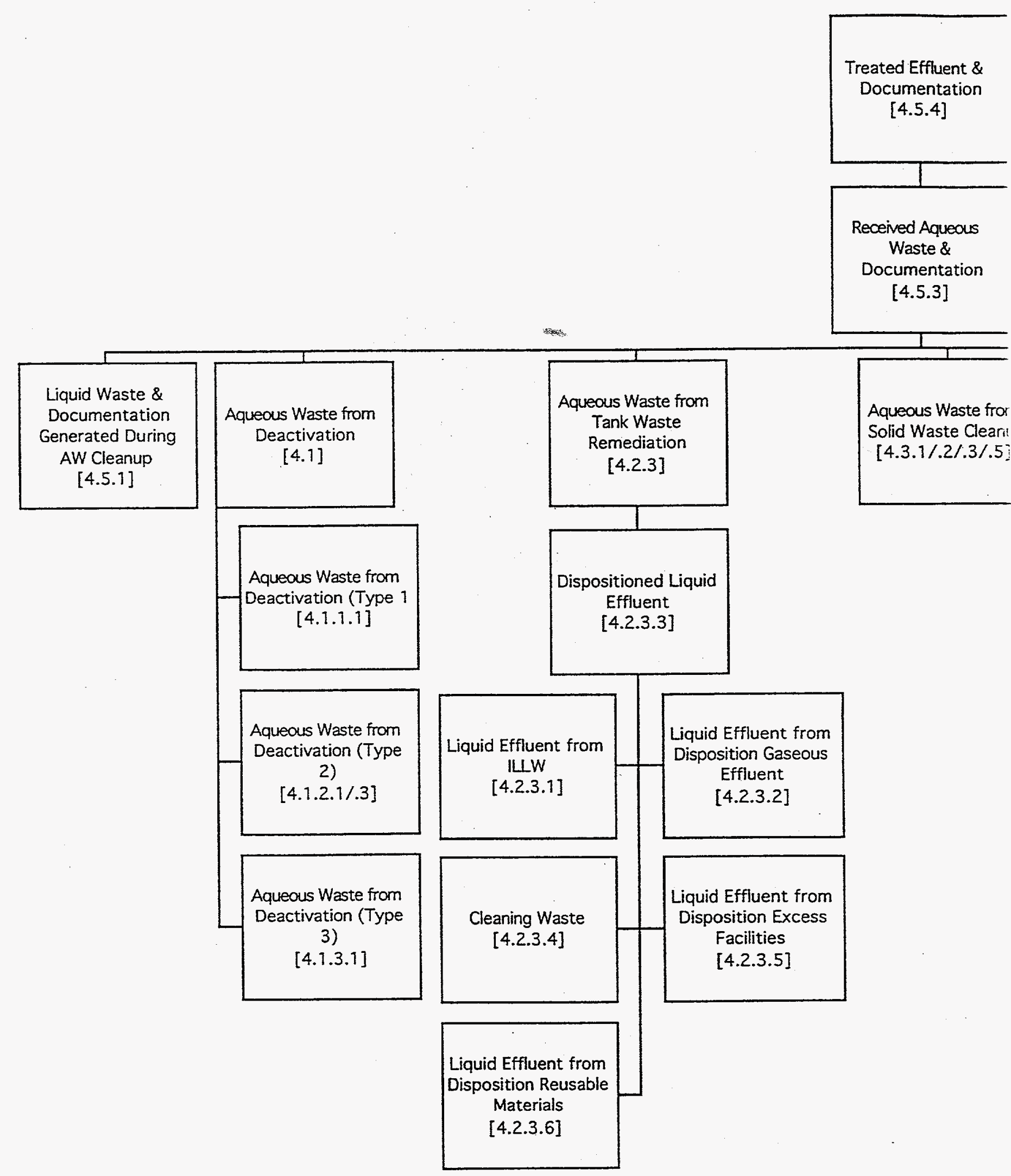


Effluent \& mentation 1.5.4]

id Aqueous

aste \&

mentation

4.5.3]

\begin{tabular}{|c|}
\hline cous Waste from \\
\hline $3.1 / .2 / .3 / .5]$ \\
\hline $\begin{array}{c}\text { Aqueous Waste from } \\
\text { Remedy/Restore } \\
{[4.4 .4]}\end{array}$ \\
\hline Groundwater \\
Treatment \\
Contaminated \\
Materials \\
{$[4.4 .5]$}
\end{tabular}

Figure 1-12. Treated Effluent and Documentation 


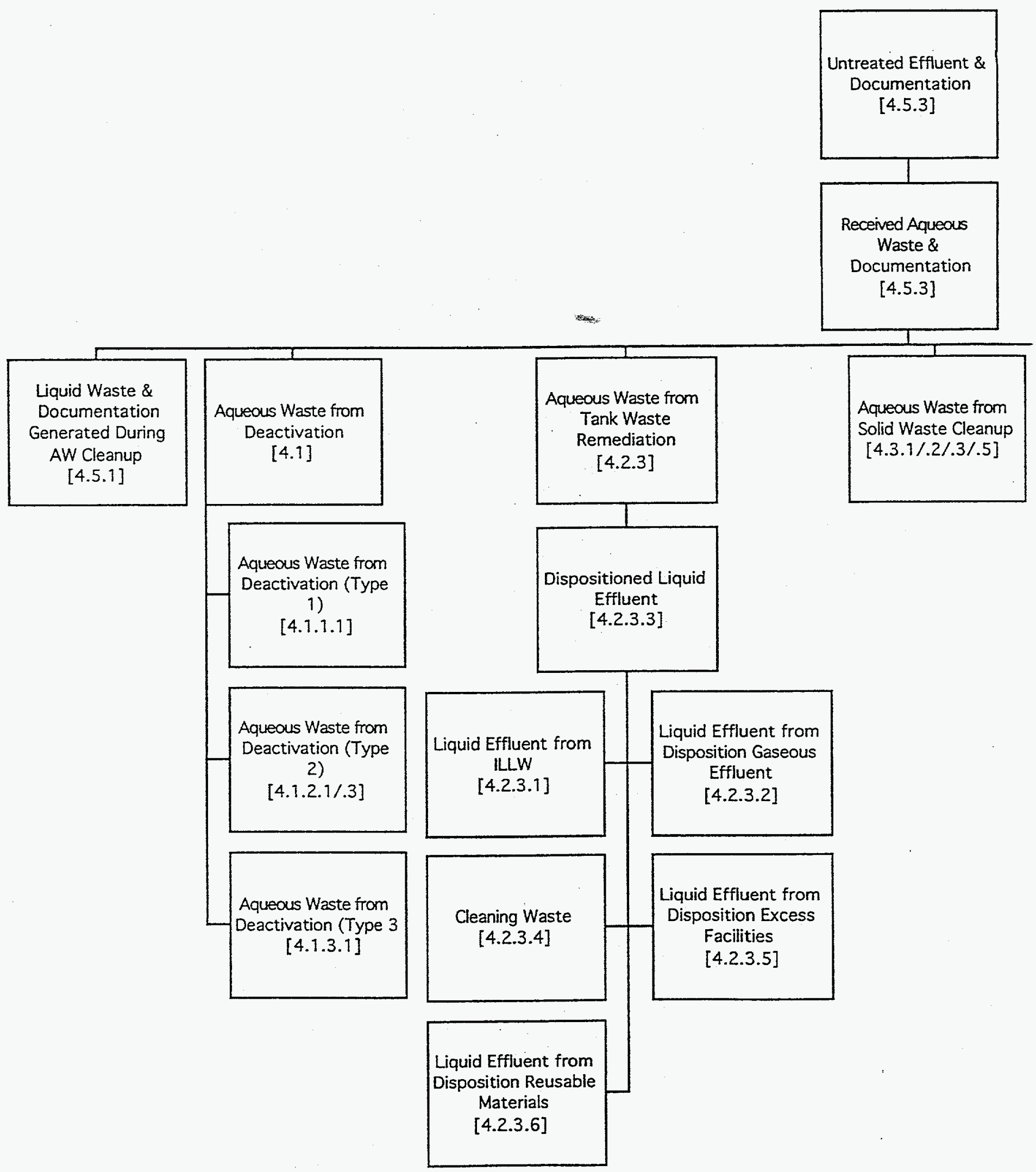




\section{fluent \&}

ation

]

\begin{tabular}{l}
\hline \\
\hline \\
\hline ueous \\
$\&$ \\
tation \\
]
\end{tabular}

\begin{tabular}{l}
\hline \\
Naste from \\
tte Cleanup \\
$2 / .3 / .5]$
\end{tabular}
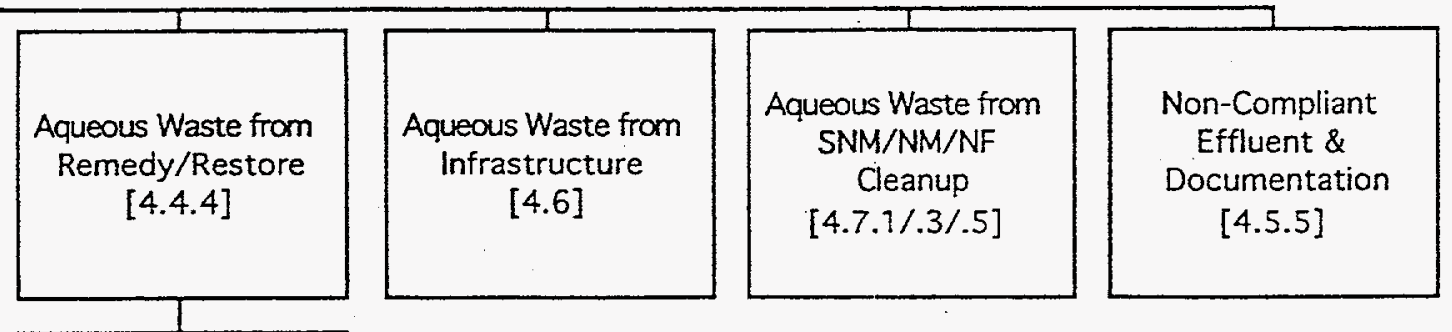

\section{Groundwater \\ Treatment \\ Contaminated \\ Materials \\ [4.4.5]}

Figure 1-13. Untreated Effluent and Documentation 


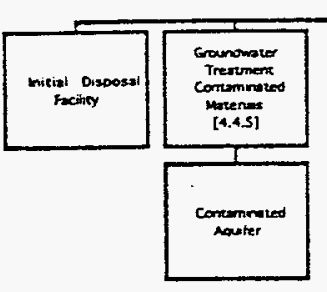

$+\infty$
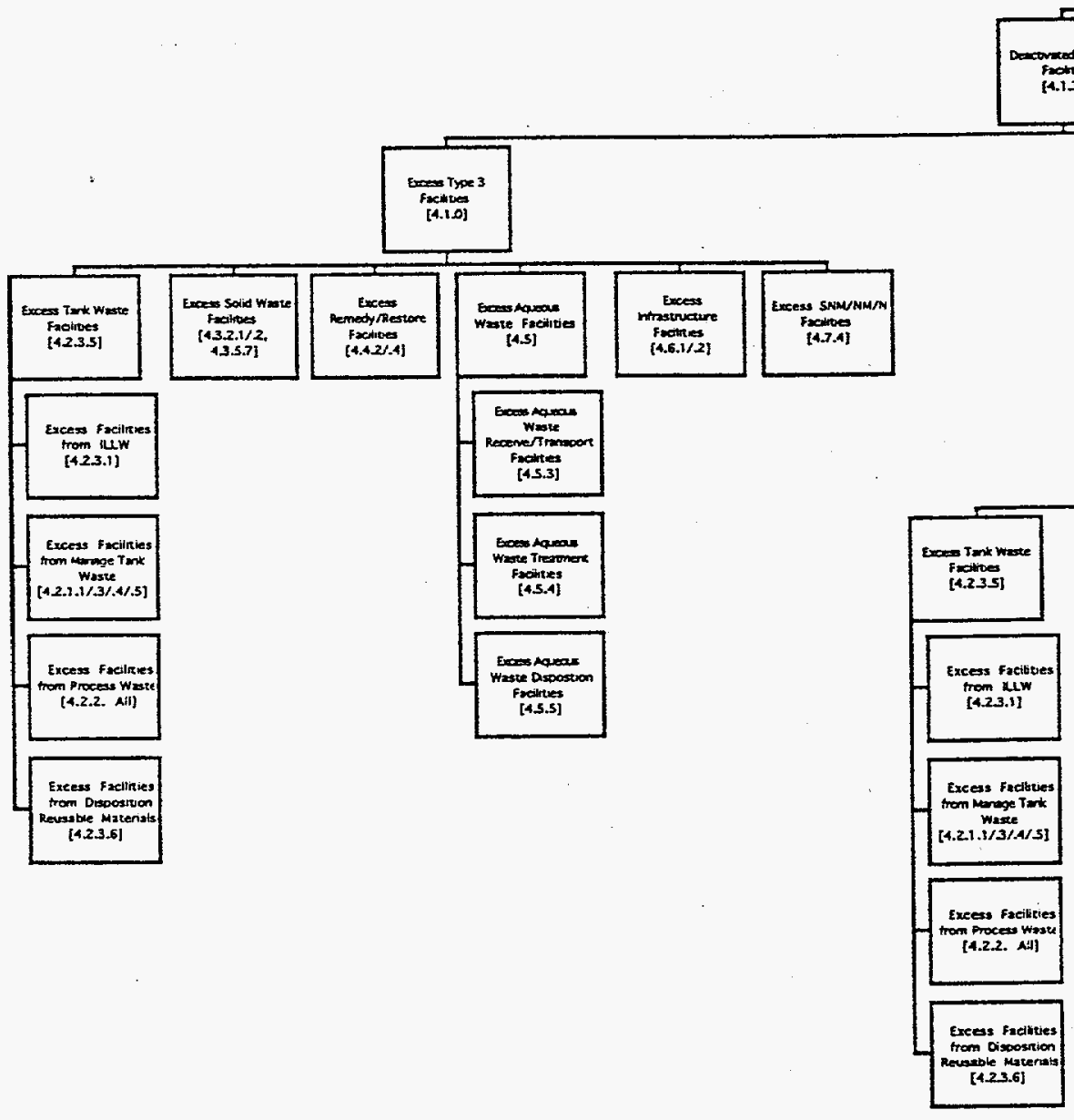


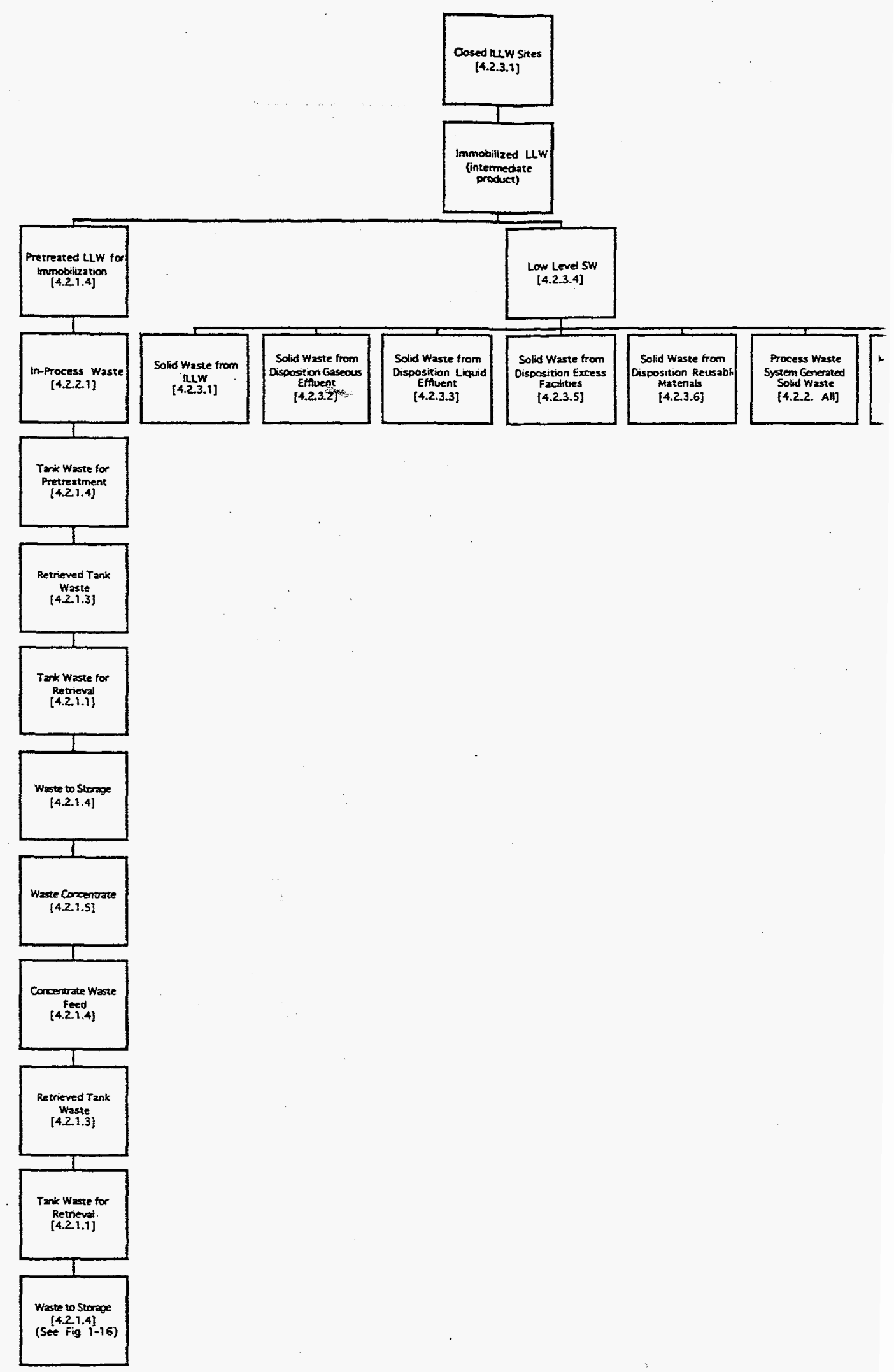


Low Leve SW [4.2.3.3.

Solid Waste from Oispositon Excess

Solid Waste from

Process Wraste Mosition Reusabh Matenals Solid Waste
Sold [4.2.2. All]

Manage Tank Waste Syxem Generted [4.2.1.All] 


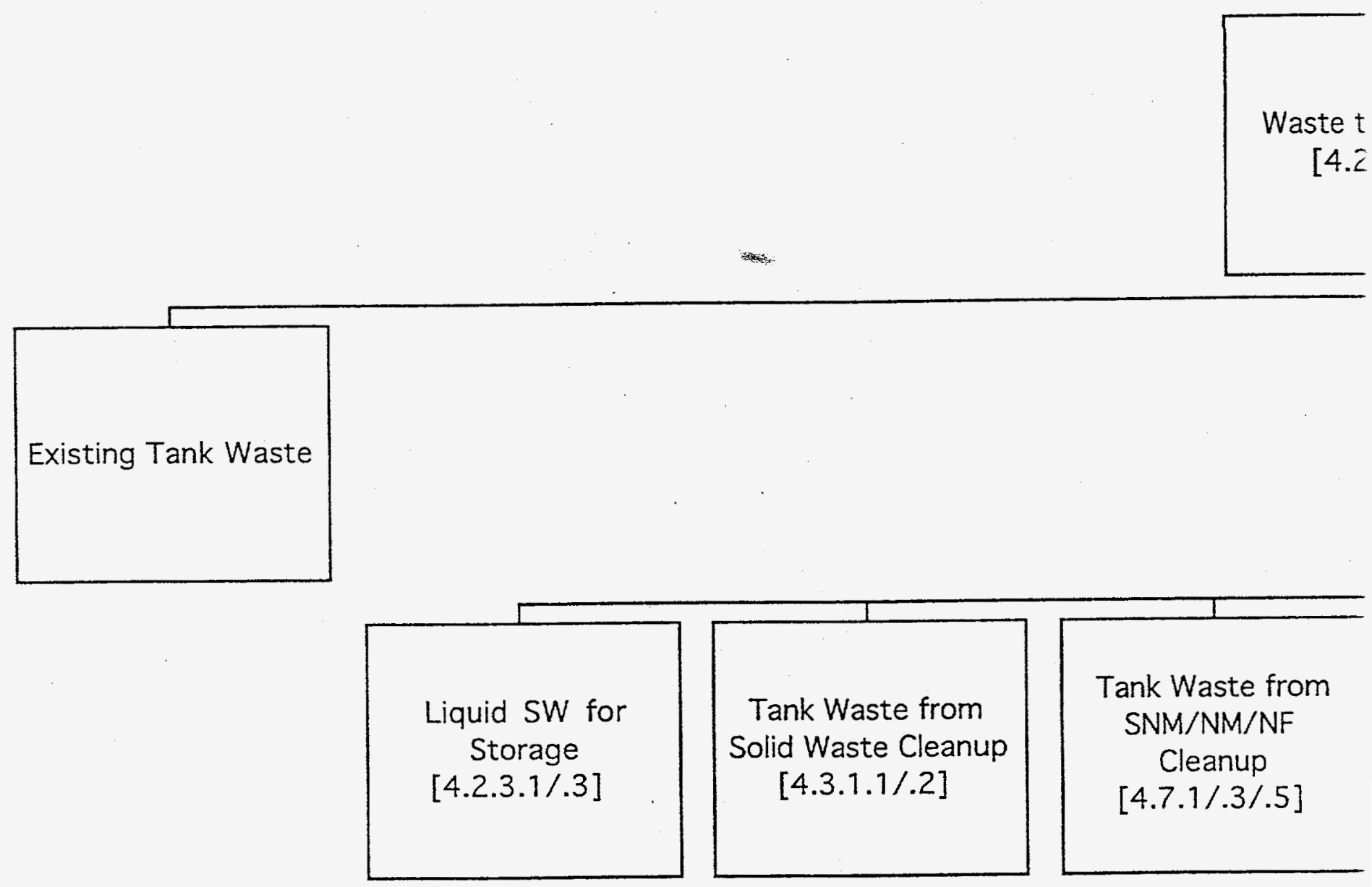


New Tank Waste

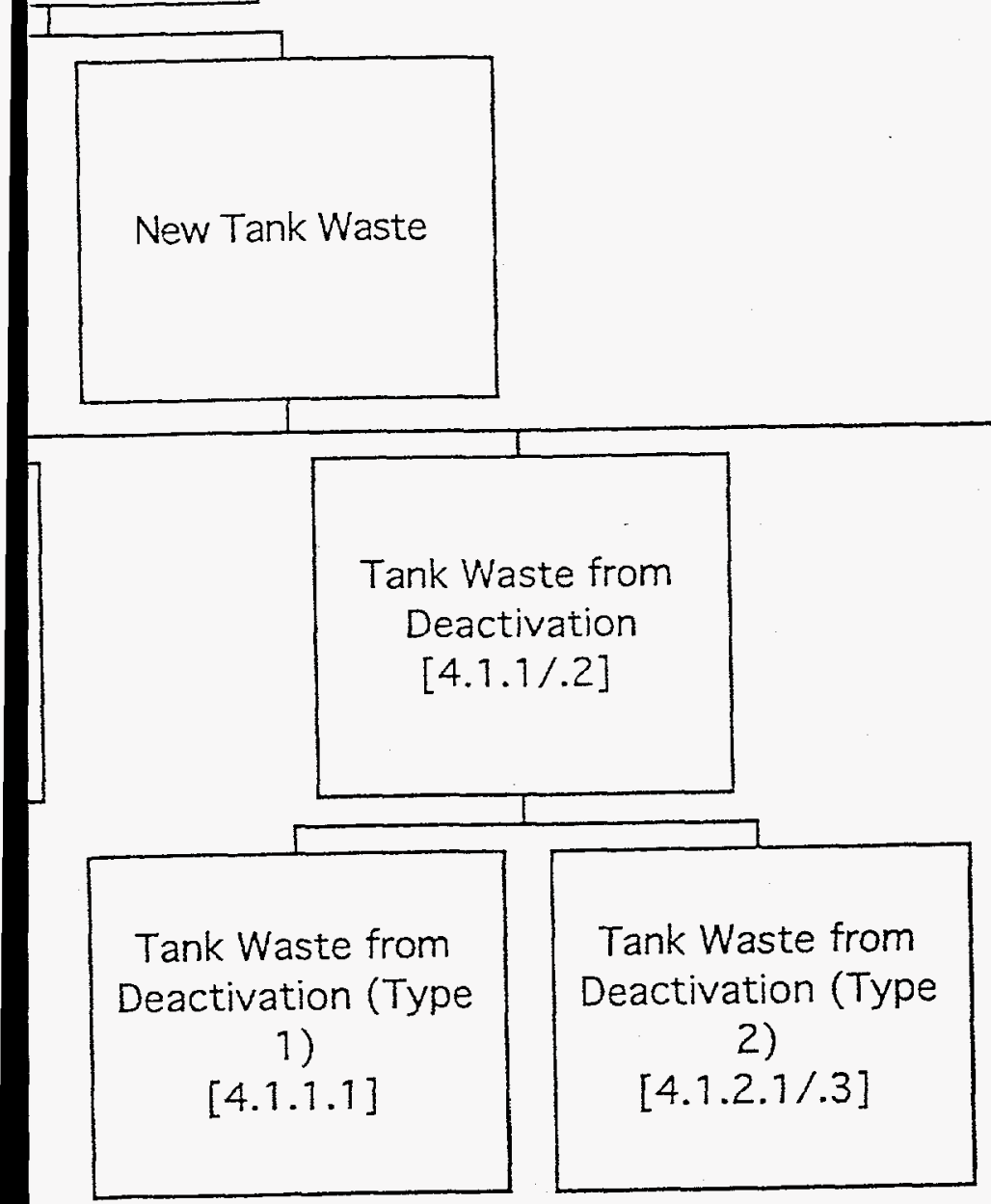

Tank Waste from Remedy/Restore [4.4.4]
Tank Waste from Aqueous Waste Processing [4.5.5] 


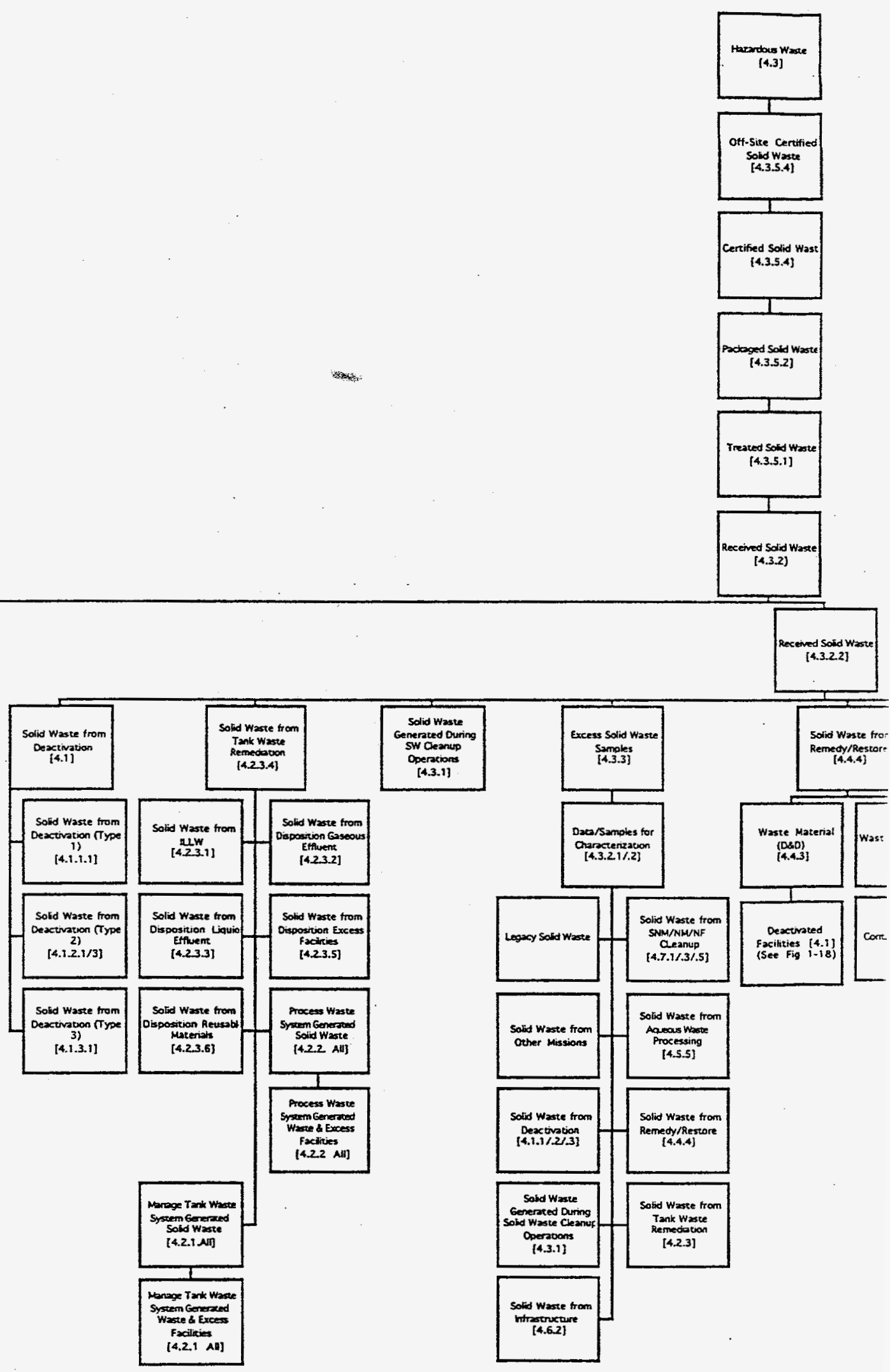




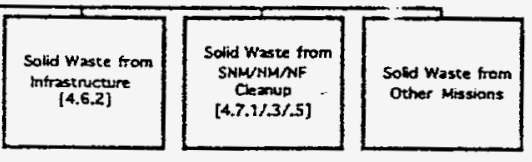

Waste Materiat

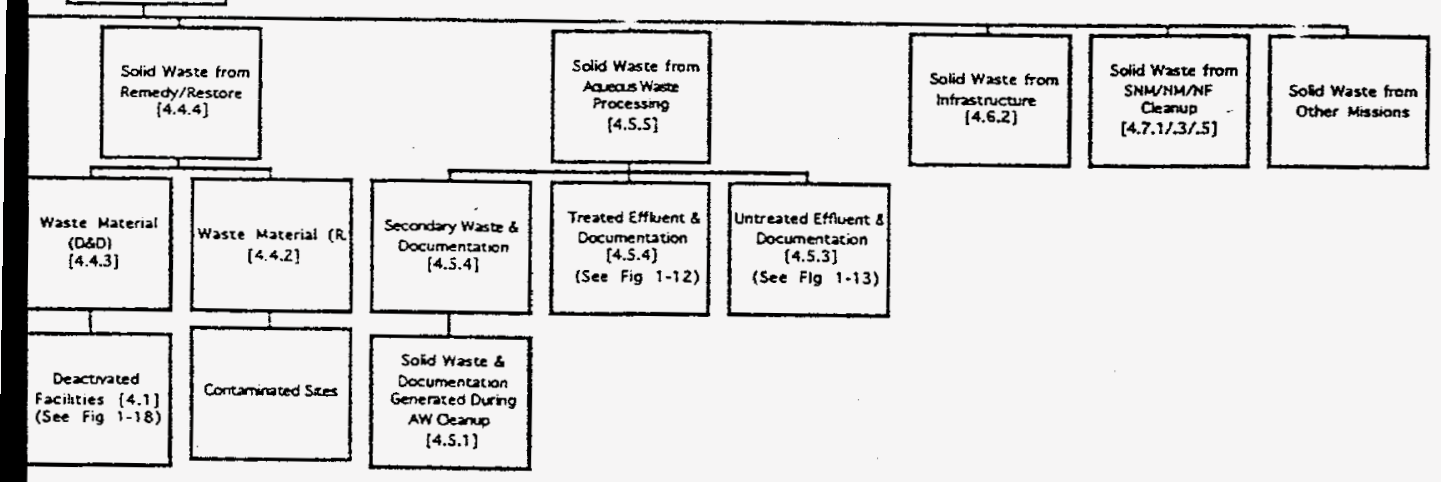

Figure 1-17. Hazardous Wreir 


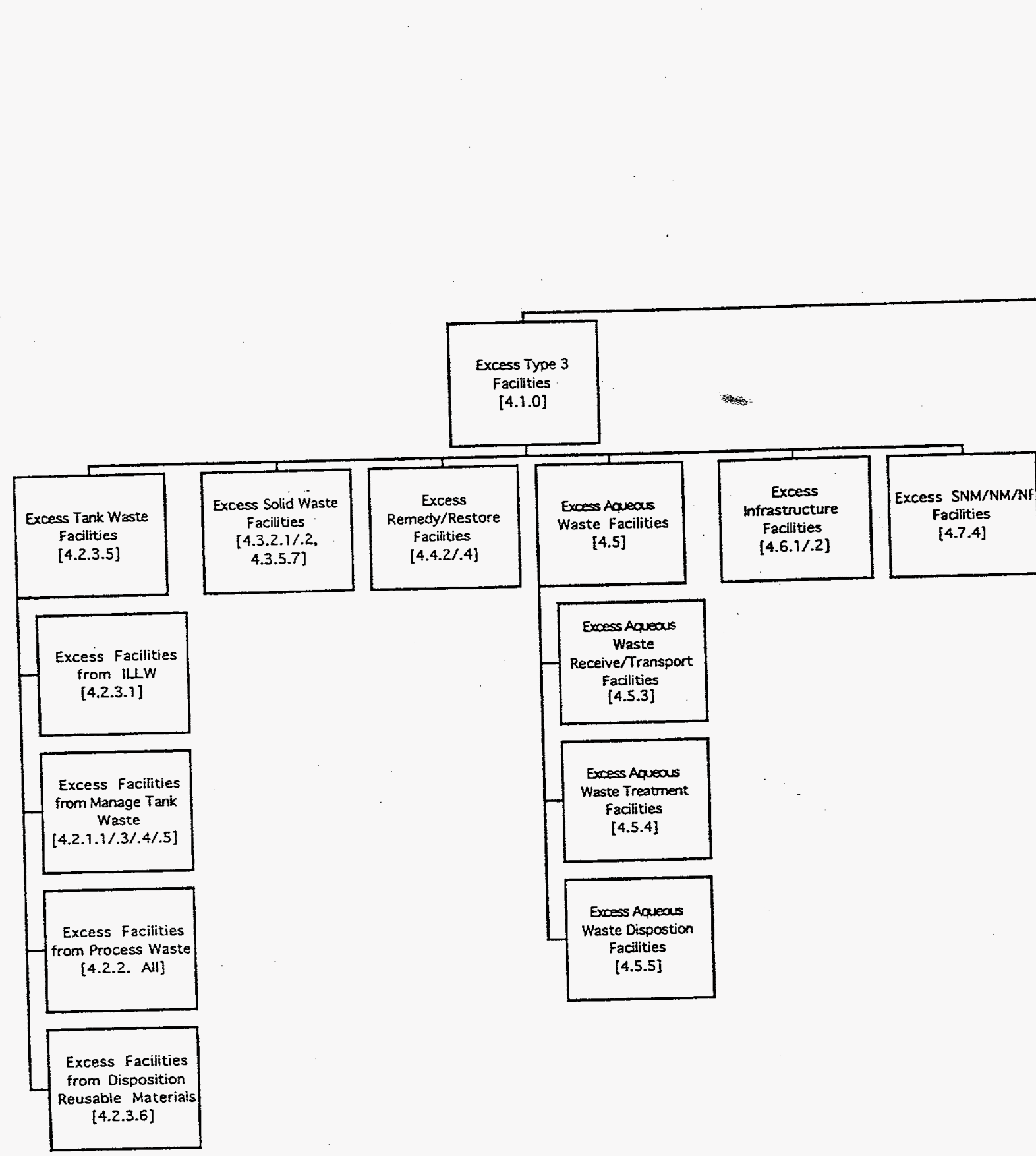

Deactivaced

[4.1]

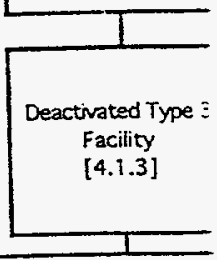

cess Type 3

Facilities

Excess

4.3.2.1/.2

medy/Restor

Facilities

te Facilities

Facilities

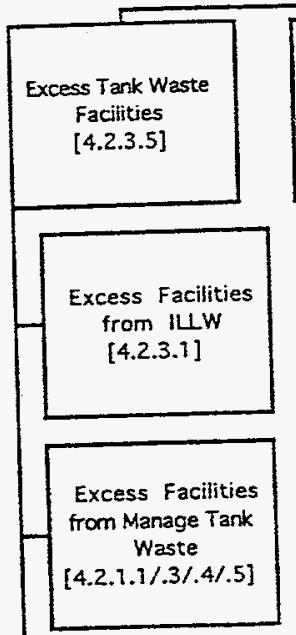

Excess Facilities from Process Waste

[4.2.2. All]

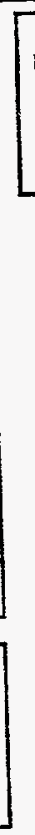

Excess Facilities from Disposition Reusable Materials [4.2.3.6] 
Deactivated

Facilities

[4.1]

\begin{tabular}{l}
\hline 1 \\
setivated Type 3 \\
Facility \\
{$[4.1 .3]$}
\end{tabular}

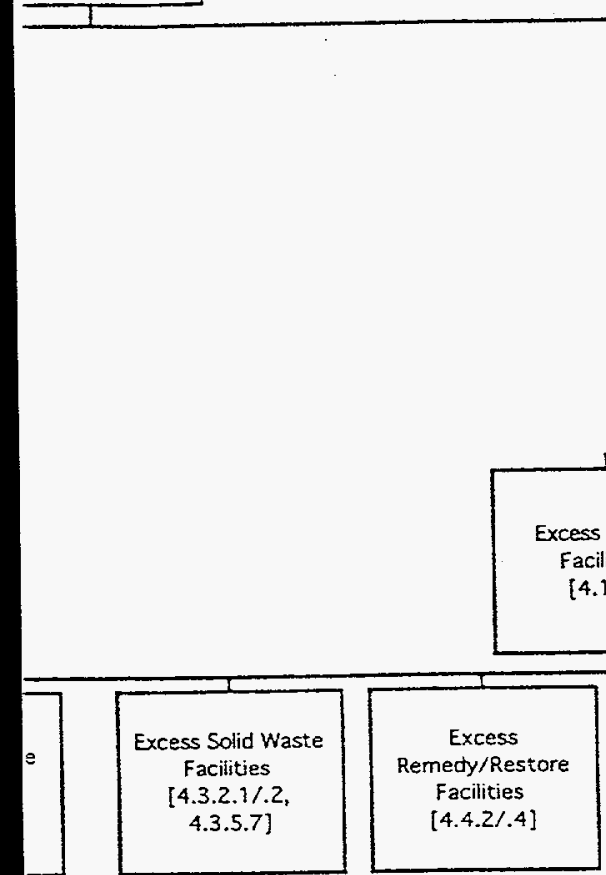

Stabilized Type 3

[4.1.2.1]

\section{Type \\ [4.1.0\}} acilities

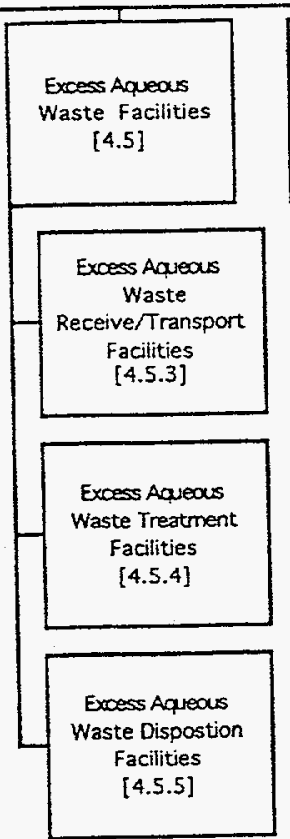

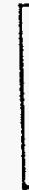

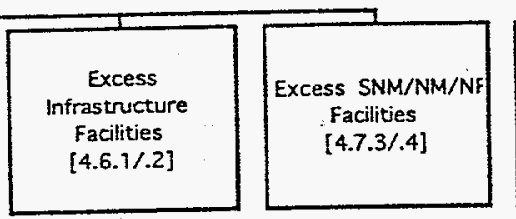

lities

n

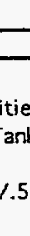

ities

Waste

[i1]

ies

Tank

$.5]$

]

ilities

sition

terials
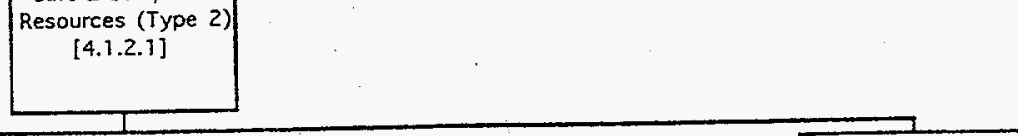


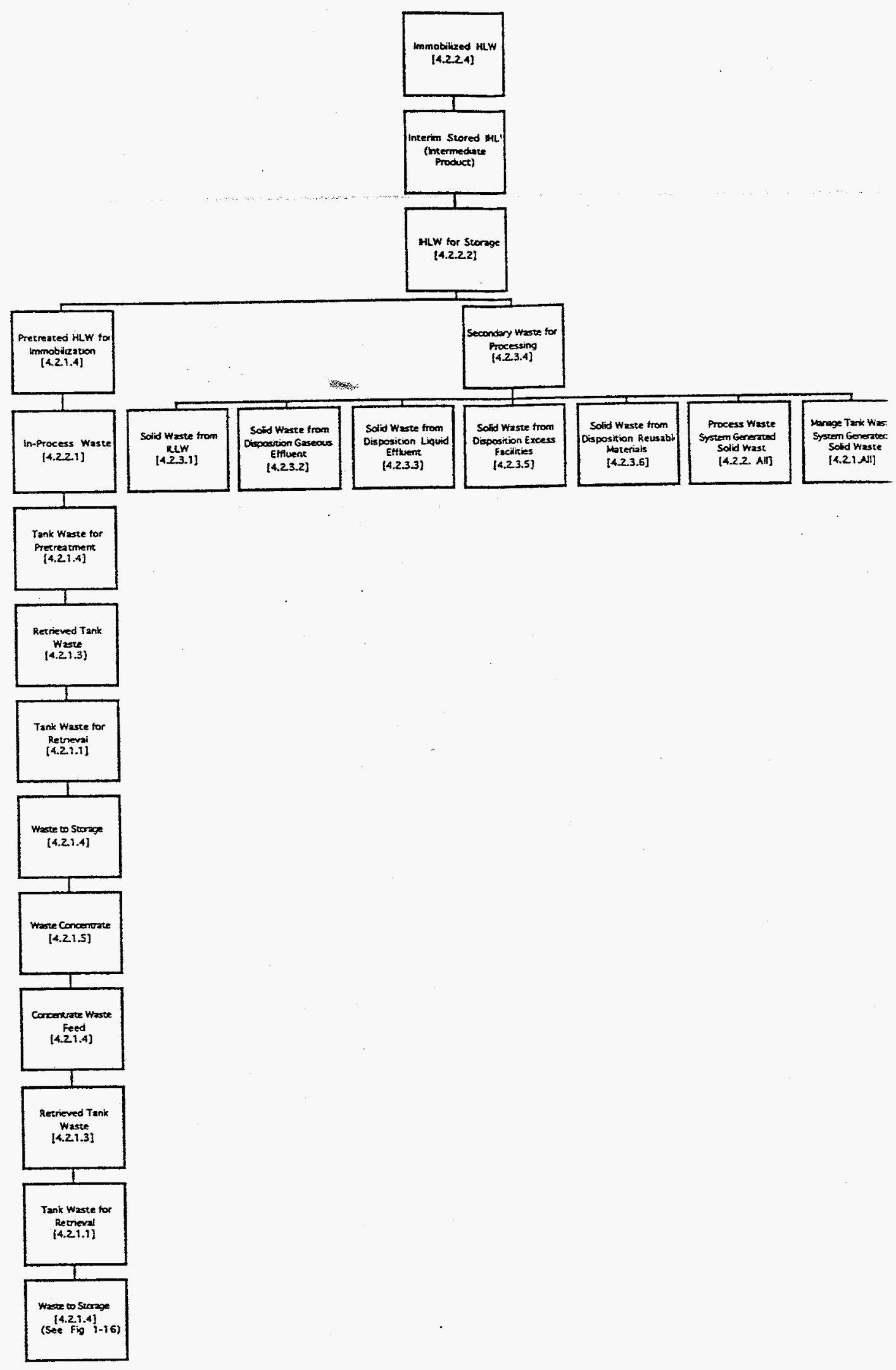




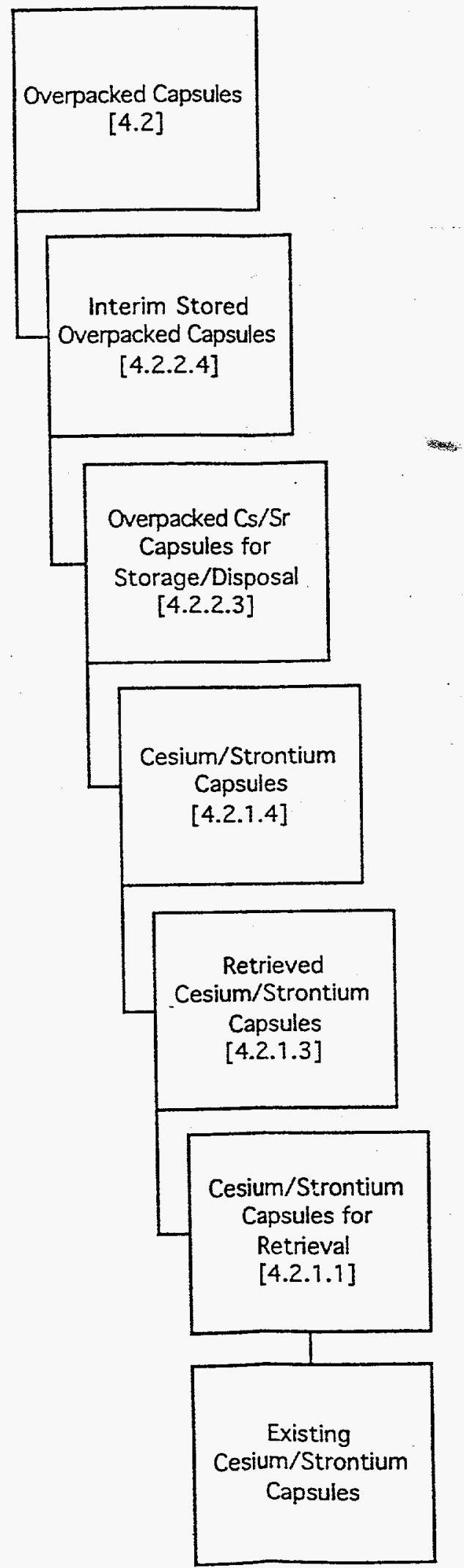




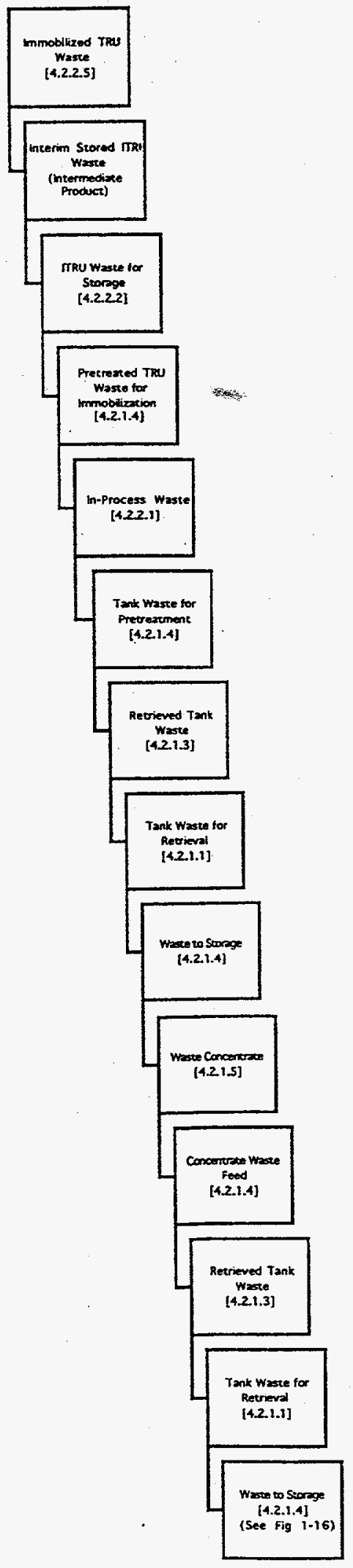




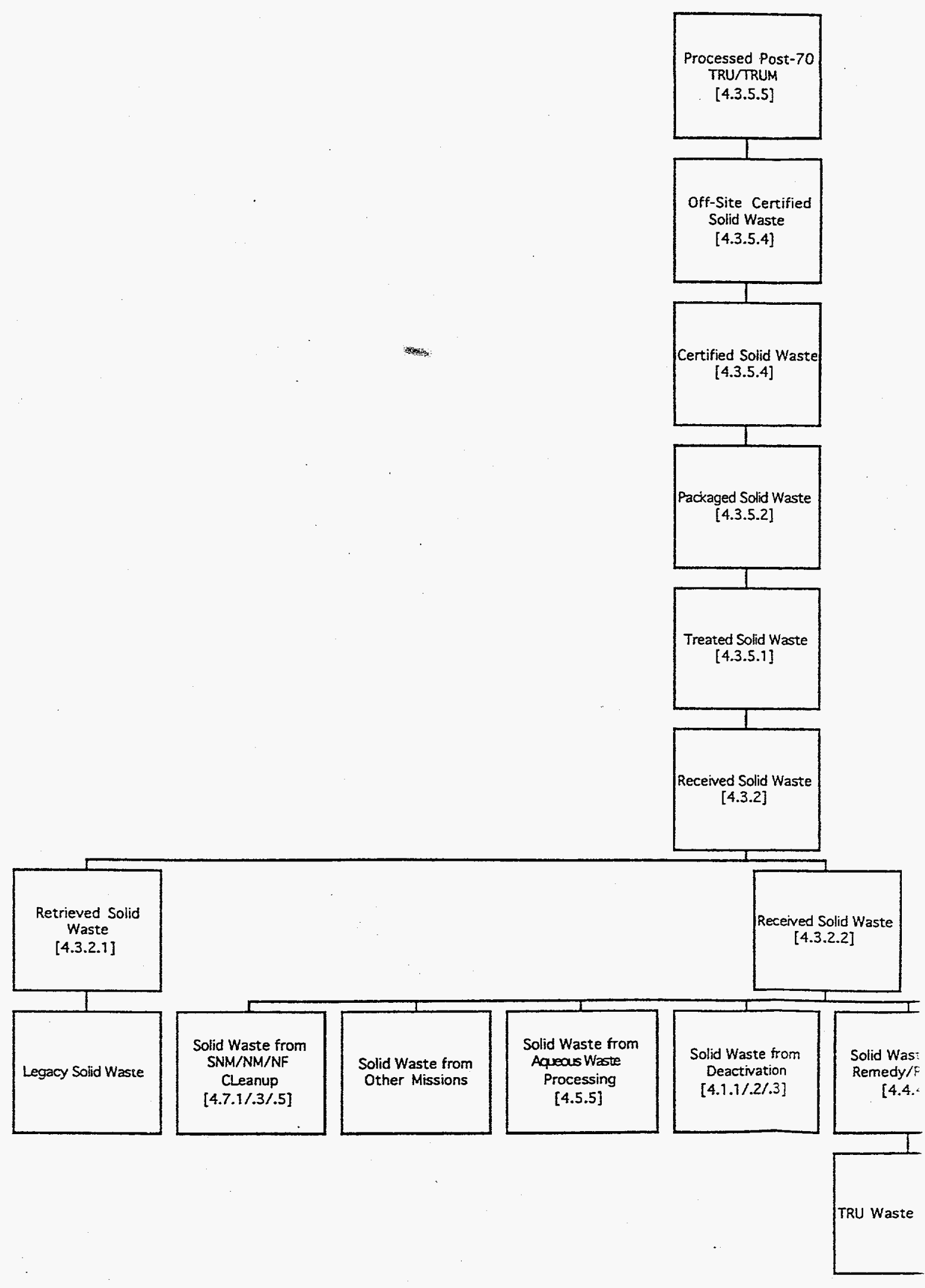



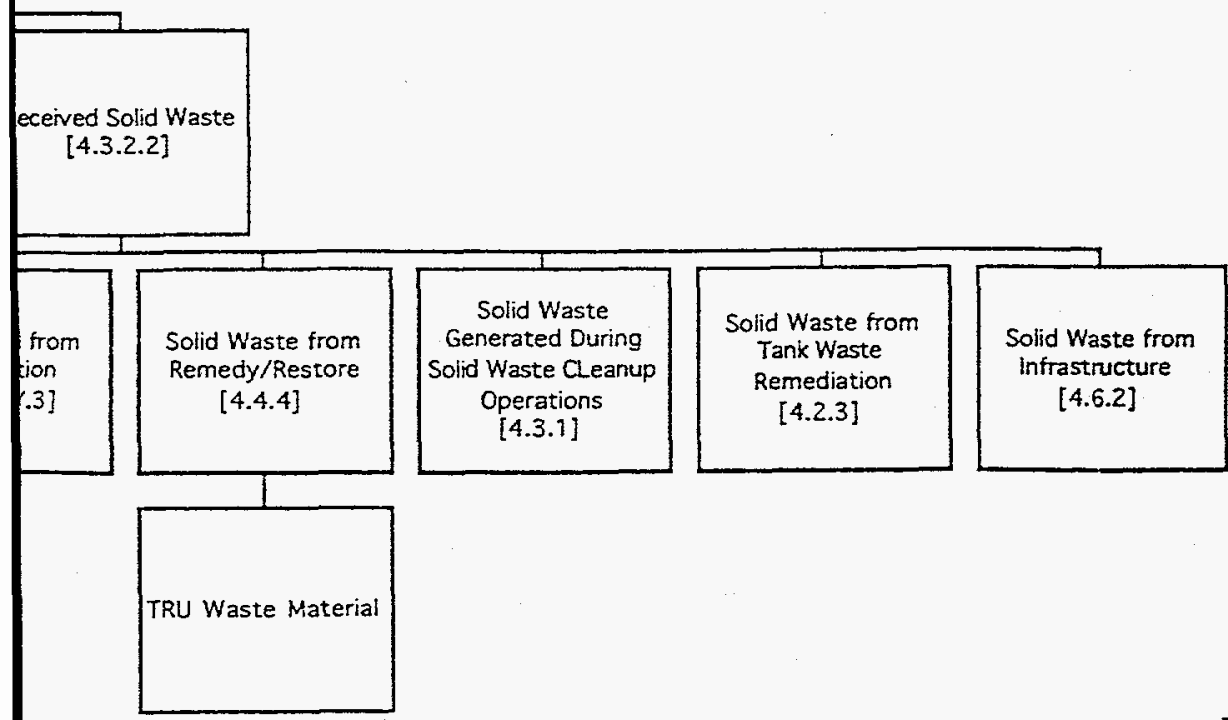


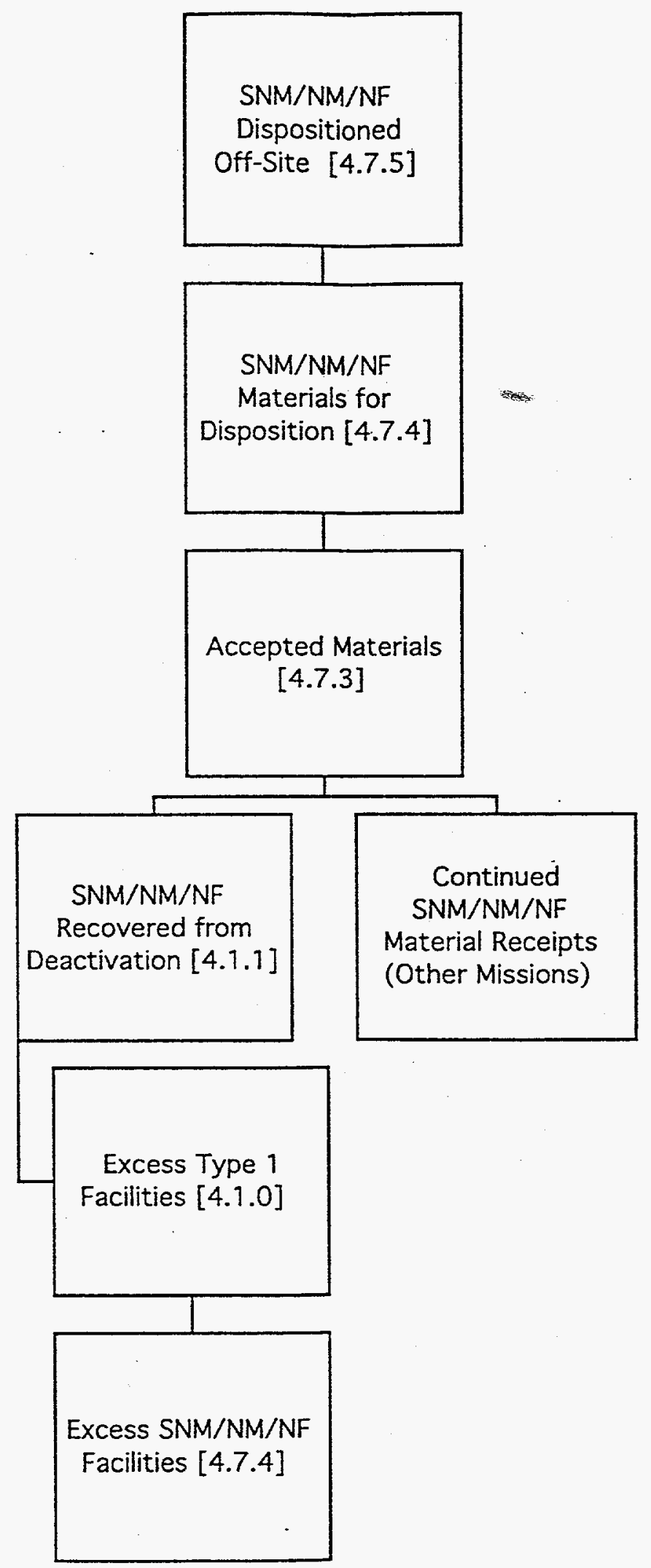




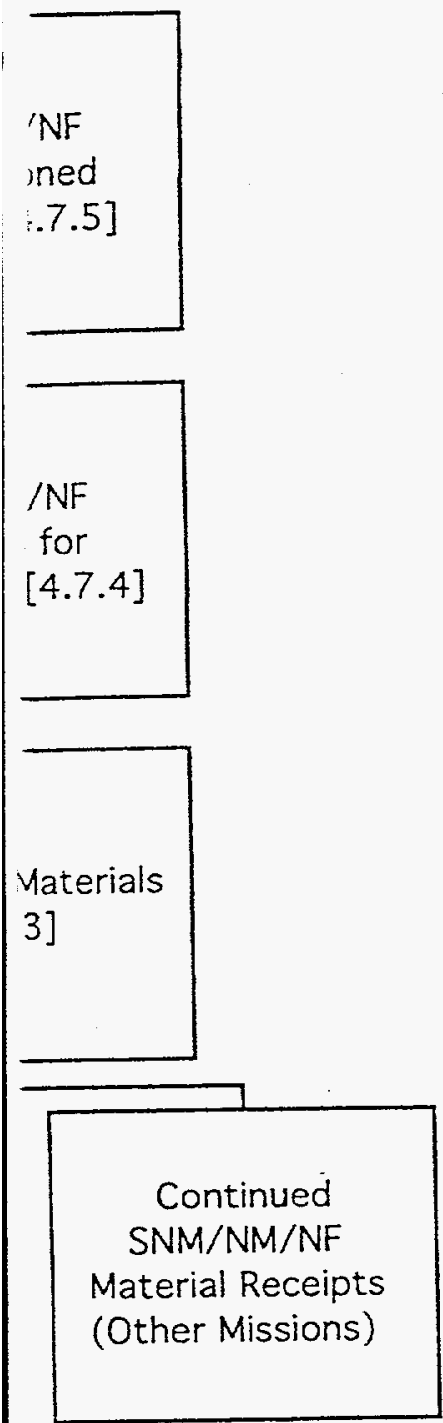

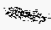




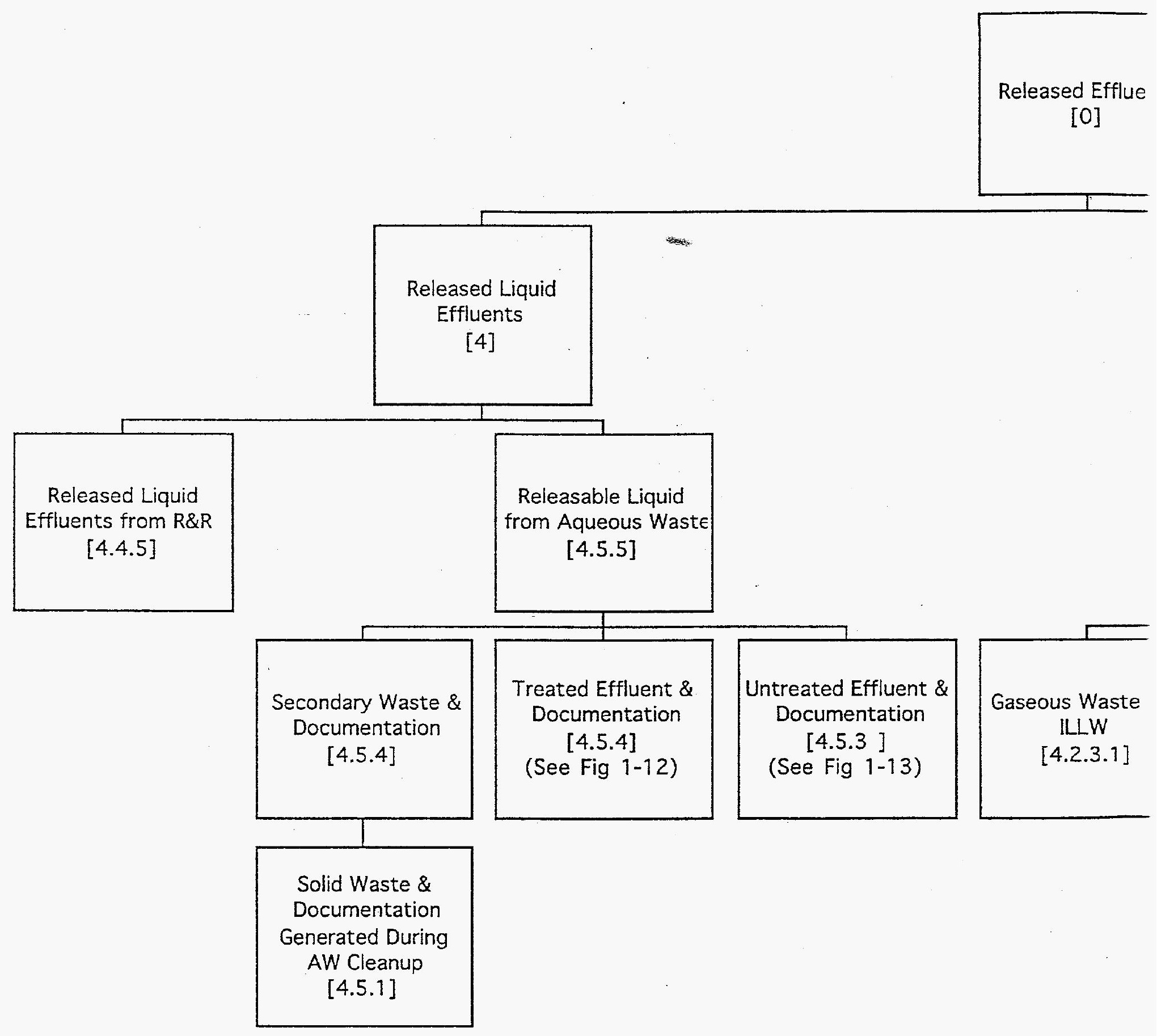


ied Effluents

[0]

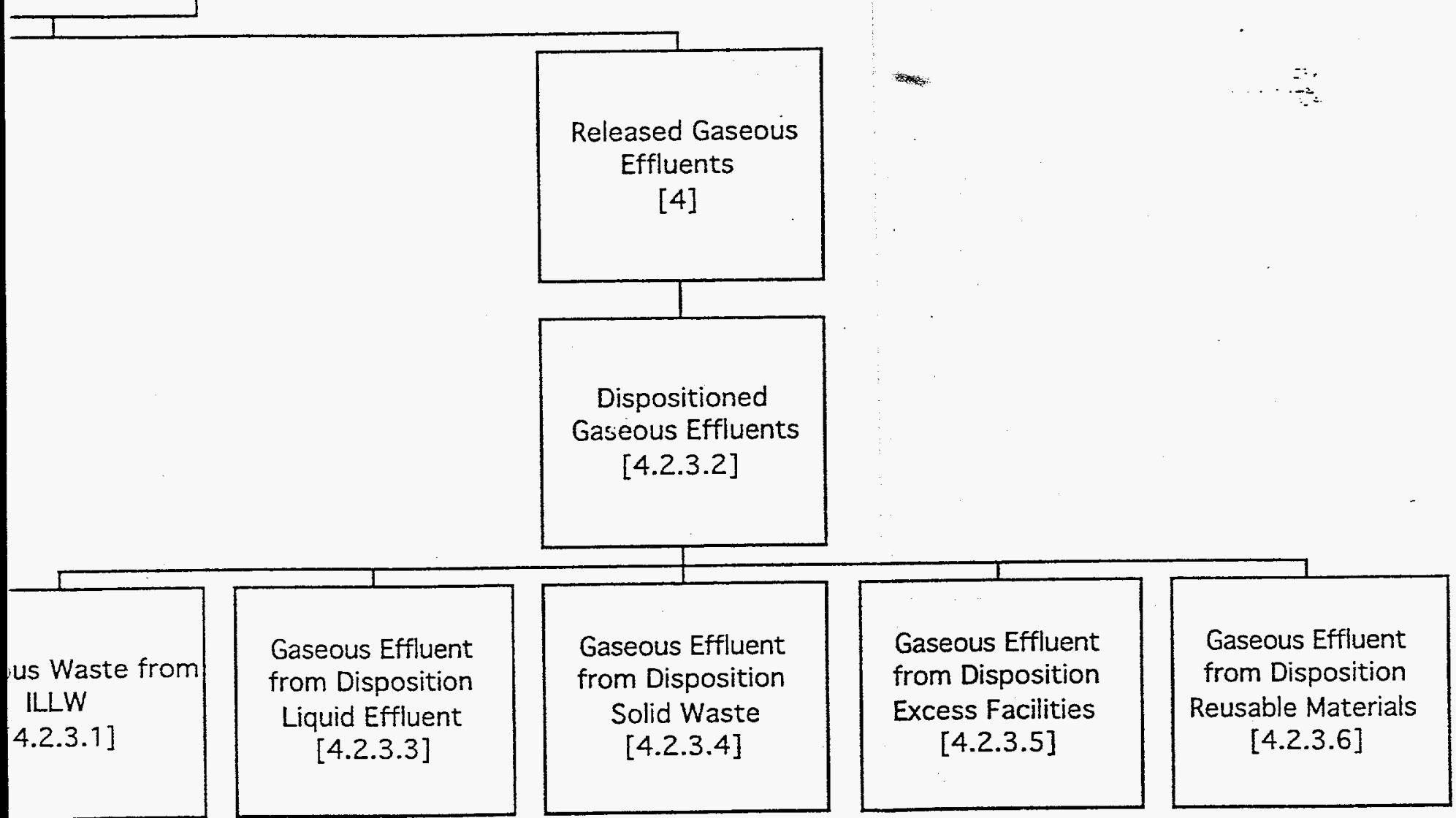

Figure 1-24. Released Effluents 


\subsection{PRODUCT DESCRIPTIONS}

Information contained in the tables in this section includes the name of the function and its definition as contained in the functional analysis. The "Product" column of the table lists, in alphabetical order, each product contained in the product breakdown structure. The "Description" column contains a definition of each product.

(Product descriptions to be provided in the final version of the document.) 
TABLE 2-1 Product Descriptions

\begin{tabular}{|l|l|}
\hline Product & Description \\
\hline Accepted Materials & $\begin{array}{l}\text { Materials that meet the acceptance criteria and their } \\
\text { form, type, consistency, and quantity have been } \\
\text { verified. }\end{array}$ \\
\hline Allocated Resources & $\begin{array}{l}\text { Financial resources authorized to the implementing } \\
\text { organization for completion of the function }\end{array}$ \\
\hline Aqueous Waste from Deactivation & $\begin{array}{l}\text { Waste water containing TRU, radioactive or } \\
\text { hazardous materials resulting from deactivation of } \\
\text { facilities. }\end{array}$ \\
\hline Aqueous Waste from Deactivation (Type 1) & $\begin{array}{l}\text { Waste water containing TRU, radioactive or } \\
\text { hazardous materials resulting from deactivation of } \\
\text { type 1 facilities. }\end{array}$ \\
\hline Aqueous Waste from Deactivation (Type 2) & $\begin{array}{l}\text { Waste water containing radioactive or hazardous } \\
\text { materials resulting from deactivation of type 2 } \\
\text { facilities. }\end{array}$ \\
\hline Aqueous Waste from Deactivation (Type 3) & $\begin{array}{l}\text { Waste water containing hazardous materials } \\
\text { resulting from deactivation of type 3 facilities. }\end{array}$ \\
\hline Aqueous Waste from Infrastructure & $\begin{array}{l}\text { Aqueous waste containing materials resulting from } \\
\text { correction of unsafe or non-compliant conditions or } \\
\text { from providing common services in support of the } \\
\text { Hanford Cleanup mission. }\end{array}$ \\
\hline Authorization for Transfer of Resources & $\begin{array}{l}\text { Low level or low level mixed aqueous waste } \\
\text { needing treatment. }\end{array}$ \\
\hline Aqueous Waste from Tank Waste Remediation & $\begin{array}{l}\text { All liquid waste that meets the acceptance criteria of } \\
\text { the Manage Aqueous Wastes function. Includes } \\
\text { liquid wastes with low level radioactive and } \\
\text { hazardous contamination levels. }\end{array}$ \\
\hline Aqueous Waste from Remedy/Restore & $\begin{array}{l}\text { Low level or low level mixed aqueous waste } \\
\text { resulting from solid waste cleanup operations. }\end{array}$ \\
\hline Aqueous Waste from SNM/NM/NF Cleanup & $\begin{array}{l}\text { All liquid waste that meets the acceptance criteria of } \\
\text { the Manage Aqueous Wastes function. Includes } \\
\text { liquid wastes with low level radioactive and } \\
\text { hazardous contamination levels. }\end{array}$ \\
\hline $\begin{array}{l}\text { Approval of the recommended disposition of } \\
\text { resources that satisfy the transfer requirements and } \\
\text { constraints for transfer outside of mission. }\end{array}$ \\
\hline
\end{tabular}


TABLE 2-1 Product Descriptions (Continued)

\begin{tabular}{|c|c|}
\hline Product & Description \\
\hline Certified Solid Waste & $\begin{array}{l}\text { This is solid waste that meets the certification } \\
\text { requirements that allow either on-site or off-site } \\
\text { disposition. }\end{array}$ \\
\hline Certified Solid Waste Archive Data and Samples & $\begin{array}{l}\text { This is archive data and samples that were part of } \\
\text { the solid waste certification process that were } \\
\text { requested to support further certification work. }\end{array}$ \\
\hline Certified Solid Waste Data and Samples & $\begin{array}{l}\text { This is data and samples that were part of the solid } \\
\text { waste certification process that require archival } \\
\text { storage. }\end{array}$ \\
\hline Cesium/Strontium Capsules & $\begin{array}{l}\text { Cs/Sr capsules in storage at Hanford or returned } \\
\text { from offsite sources to Hanford. }\end{array}$ \\
\hline Cesium/Strontium Capsules for Retrieval & $\begin{array}{l}\text { Cesium and strontium capsules residing in storage } \\
\text { that have been identified for transfer to the Process } \\
\text { Waste function for final disposition. }\end{array}$ \\
\hline Cleaning Waste & $\begin{array}{l}\text { Liquids evolved from management of solid waste. } \\
\text { These liquids are primarily expected from waste } \\
\text { decontamination, but may also be generated from } \\
\text { other material management activities (e.g., package } \\
\text { or shipping cask decontamination, material } \\
\text { stabilization). }\end{array}$ \\
\hline Cleanup Program Information & $\begin{array}{l}\text { Cleanup Program Information consisting of program } \\
\text { plans for review, comment and information, } \\
\text { progress information, and resource allocation } \\
\text { information to the OBTAIN PUBLIC TRUST function } \\
\text { for public review and information. }\end{array}$ \\
\hline Closed ILLW Sites & $\begin{array}{l}\text { Solidified or otherwise immobilized and stabilized } \\
\text { LLW resulting from high level tank waste } \\
\text { processing, in engineered disposal structures and } \\
\text { their sites that have been closed with appropriate } \\
\text { long-term monitoring instrumentation in place. }\end{array}$ \\
\hline Closed Waste Disposal Facility & $\begin{array}{l}\text { A waste disposal facility containing LLW and LLMW } \\
\text { resulting from remediation and environmental } \\
\text { restoration of Hanford sites. }\end{array}$ \\
\hline
\end{tabular}


TABLE 2-1 Product Descriptions (Continued)

\begin{tabular}{|l|l|}
\hline Product & Description \\
\hline Closure-Ready DSTs & $\begin{array}{l}\text { DSTs that have been emptied of waste, } \\
\text { decontaminated, isolated, and are ready to be } \\
\text { transferred to the site-level Deactivate Facilities } \\
\text { function (4.1) (D\&D) for closure. This does not } \\
\text { preclude external, site reuse. }\end{array}$ \\
\hline Closure-Ready SSTs & $\begin{array}{l}\text { SSTs that have been emptied of waste, } \\
\text { decontaminated, isolated, and are ready for transfer } \\
\text { to the sitewide Deactivate Facilities function (4.1) } \\
\text { (D\&D) for closure. }\end{array}$ \\
\hline Concentrate Waste Feed & $\begin{array}{l}\text { Liquid waste, with required characterization } \\
\text { information, delivered to the evaporator for } \\
\text { processing into a low-volume concentrate. }\end{array}$ \\
\hline Conditioned Waste for Sampling & $\begin{array}{l}\text { Solid and liquid wastes that have been conditioned } \\
\text { before initiating transfer that have been identified } \\
\text { for characterization requiring laboratory or in situ } \\
\text { analysis. }\end{array}$ \\
\hline Contaminated aquifer & $\begin{array}{l}\text { Uncontained, untreated, unmodified contaminated } \\
\text { aquifer. }\end{array}$ \\
\hline Contaminated sites & $\begin{array}{l}\text { RA land to be remediated with areas of radiological } \\
\text { and/or hazardous contamination. }\end{array}$ \\
\hline Deactivated Facilities & $\begin{array}{l}\text { This is new waste information and samples } \\
\text { obtained during solid waste access and removal } \\
\text { operations and through the verification process } \\
\text { associated with acceptance. }\end{array}$ \\
\hline Data/Samples for Characterization & $\begin{array}{l}\text { Facilities placed in an acceptable condition for } \\
\text { demolition or as a transferrable resource. }\end{array}$ \\
\hline Deactivated facilities removed & $\begin{array}{l}\text { Type 3 facilities with hazardous materials stabilized, } \\
\text { terminated utility services and facitity interties. }\end{array}$ \\
\hline $\begin{array}{l}\text { Type 4 facility with terminated utility services and } \\
\text { facility interties. }\end{array}$ \\
\hline $\begin{array}{l}\text { Decontaminated and demolished retired surplus } \\
\text { facilities removed. }\end{array}$ \\
\hline
\end{tabular}


TABLE 2-1 Product Descriptions (Continued)

\begin{tabular}{|l|l|}
\hline Product & Description \\
\hline Defined Work Package & $\begin{array}{l}\text { Documentation describing the specific work; work } \\
\text { authorization, description, procedures, resource } \\
\text { limits and schedules; controlling performance of the } \\
\text { function }\end{array}$ \\
\hline Direction \& Control & $\begin{array}{l}\text { Management guidance based on the status of } \\
\text { implementation of the Defined Work Packages }\end{array}$ \\
\hline Dispositioned Gaseous Effluent & $\begin{array}{l}\text { Conditioned gases appropriate for discharge } \\
\text { directly to the environment from process and } \\
\text { containment buildings. }\end{array}$ \\
\hline Dispositioned Liquid Effluent & $\begin{array}{l}\text { Treated liquid effluent from the DLE function to the } \\
\text { Manage Aqueous Waste function. May contain } \\
\text { environmentally releasable effluent. }\end{array}$ \\
\hline Dispositioned Solid Waste (TWRS) & $\begin{array}{l}\text { Dispositioned solid waste includes all packaged and } \\
\text { shipped waste that meets the disposal criteria for } \\
\text { the appropriate disposal destination, including } \\
\text { sanitary, hazardous, mixed, and radioactive wastes. } \\
\text { This includes failed melter packages as high-level } \\
\text { solid waste to a geologic repository, minus any } \\
\text { scrap glass that can be fed back into the IHLW } \\
\text { process via output interface 4.2.3.4 O7, Scrap } \\
\text { Glass. }\end{array}$ \\
\hline Enhanced Local Economy & $\begin{array}{l}\text { The management organization, infrastructure, } \\
\text { principles and policies established to formulate and } \\
\text { execute the programs required to complete the } \\
\text { Hanford cleanup mission successfully. }\end{array}$ \\
\hline Effective Management System & $\begin{array}{l}\text { Cleanup resources that have been expended in a } \\
\text { manner to support independence of the } \\
\text { local/private sector economy. This can be achieved } \\
\text { through development of public/private sector } \\
\text { partnerships, transfer of technologies for use } \\
\text { elsewhere, etc. Also, expenditure of these } \\
\text { resources should, where possible, provide national } \\
\text { and international benefit by making technology and } \\
\text { expertise broadly available. }\end{array}$ \\
\hline $\begin{array}{l}\text { The excess facilities and equipment from the } \\
\text { disposition function. }\end{array}$ \\
\hline Excess Aqueous Waste Disposition Facilities
\end{tabular}


TABLE 2-1 Product Descriptions (Continued)

\begin{tabular}{|l|l|}
\hline Product & Description \\
\hline Excess Aqueous Waste Facilities & $\begin{array}{l}\text { Excess receiving, treatment, storage, and } \\
\text { disposition facilities. }\end{array}$ \\
\hline $\begin{array}{l}\text { Excess Aqueous Waste Receive/Transport } \\
\text { Facilities }\end{array}$ & $\begin{array}{l}\text { Excess facilities generated by the } \\
\text { Receive/Transport Aqueous Waste function. }\end{array}$ \\
\hline Excess Aqueous Waste Treatment Facilities & $\begin{array}{l}\text { The excess facilities and equipment from aqueous } \\
\text { waste treatment. }\end{array}$ \\
\hline Excess Facilities from DRM & $\begin{array}{l}\text { DRM excess facilities that have reached their useful } \\
\text { life and have no currently identifiable or planned } \\
\text { programmatic use in the DRM function. }\end{array}$ \\
\hline Excess Facilities from ILLW & $\begin{array}{l}\text { ILLW excess facilities that have reached their useful } \\
\text { life and have no currently identifiable or planned } \\
\text { programmatic use. }\end{array}$ \\
\hline Excess Facilities from MTW & $\begin{array}{l}\text { MTW excess facilities that have reached their } \\
\text { useful life and have no currently identifiable or } \\
\text { planned programmatic use in the MTW function. }\end{array}$ \\
\hline Excess Facilities from PW & $\begin{array}{l}\text { PW excess facilities that have reached their useful } \\
\text { life and have no currently identifiable or planned } \\
\text { programmatic use in the PW function. }\end{array}$ \\
\hline Excess Infrastructure Facilities & $\begin{array}{l}\text { Facilities used in providing basic, commonly-used } \\
\text { services, that are no longer required. }\end{array}$ \\
\hline Excess Remedy/Restore Facilities & $\begin{array}{l}\text { Remedy/Restore facilities no longer required for } \\
\text { performance of Hanford cleanup mission functions. }\end{array}$ \\
\hline Excess SNM/NM/NF Facilities & $\begin{array}{l}\text { The excess facilities and equipment associated with } \\
\text { the storage, treatment, and disposition of } \\
\text { SNMNMMNF materials. }\end{array}$ \\
\hline Excess Solid Waste Facilities & $\begin{array}{l}\text { Facilities that have had a mission in the Hanford } \\
\text { Cleanup Mission. It includes excess sites for } \\
\text { disposition (e.g. potentially contaminated retrieved } \\
\text { trench). }\end{array}$ \\
\hline $\begin{array}{l}\text { These are excess solid waste samples that will be } \\
\text { received as solid waste requiring disposition. }\end{array}$ \\
\hline
\end{tabular}


TABLE 2-1 Product Descriptions (Continued)

\begin{tabular}{|l|l|}
\hline Product & Description \\
\hline Excess Tank Waste Facilities & $\begin{array}{l}\text { TWRS (non-tank) facilities that have been emptied, } \\
\text { decontaminated, disabled, except for essential } \\
\text { surveilance and monitoring systems and are ready } \\
\text { for transfer to the site-level Deactivate Facilities } \\
\text { (4.1) function. }\end{array}$ \\
\hline Excess Type 1 Facilities & $\begin{array}{l}\text { Excess facilities containing SNM/NM/NF, and } \\
\text { radioactive waste and hazardous waste. }\end{array}$ \\
\hline Excess Type 2 Facilities & $\begin{array}{l}\text { Excess facilities containing radioactive waste and } \\
\text { hazardous waste, but no SNM/NM/NF. }\end{array}$ \\
\hline Excess Type 3 Facilities & $\begin{array}{l}\text { Excess facilities containing hazardous waste, } \\
\text { including asbestos. }\end{array}$ \\
\hline Excess Type 4 Facilities & $\begin{array}{l}\text { Excess facilities containing no radioactive waste or } \\
\text { hazardous waste. }\end{array}$ \\
\hline Existing Cesium/Strontium Capsules & $\begin{array}{l}\text { Encapsulated cesium and strontium previously } \\
\text { removed from the existing tank wastes. }\end{array}$ \\
\hline Existing Tank Waste & $\begin{array}{l}\text { Existing tank waste including waste within transfer } \\
\text { lines }\end{array}$ \\
\hline Gaseous Effluent from DEF & $\begin{array}{l}\text { Gasecus effluent generated from the process of } \\
\text { removing hazardous and radioactive inventories } \\
\text { and decontaminating excess facilities. }\end{array}$ \\
\hline Gaseous Effluent from DLE & $\begin{array}{l}\text { Vessel vent and HVAC flows from evaporator } \\
\text { process condensate treatment facility type } \\
\text { activities. }\end{array}$ \\
\hline Gaseous Effluent from DRM & $\begin{array}{l}\text { Gaseous effluent that are a byproduct from DRM } \\
\text { treatment or interim storage such as ventilation } \\
\text { exhaust. }\end{array}$ \\
\hline Gaseous Effluent from DSW & $\begin{array}{l}\text { Ghese gases are primarily expected from solid } \\
\text { waste management enclosures but may also be } \\
\text { generated from material management activities or } \\
\text { radiolysis. }\end{array}$ \\
\hline $\begin{array}{l}\text { Gaseous effluents from melter off gas, process } \\
\text { vessel offgas, and facility offgas are treated to meet } \\
\text { emission requirements and released. }\end{array}$ \\
\hline
\end{tabular}


TABLE 2-1 Product Descriptions (Continued)

\begin{tabular}{|c|c|}
\hline Product & Description \\
\hline Groundwater treatment contaminated materials & $\begin{array}{l}\text { Contaminated materials resulting from groundwater } \\
\text { extraction and treatment methods. }\end{array}$ \\
\hline Hazardous Waste & $\begin{array}{l}\text { Hazardous waste as defined by federal, state, or } \\
\text { local laws. }\end{array}$ \\
\hline ID Key Issues For PI & $\begin{array}{l}\text { Specific issues pertaining to Hanford cleanup } \\
\text { identified as significant concerns to the public. }\end{array}$ \\
\hline IHLW for Storage & $\begin{array}{l}\text { IHLW sealed in containers suitable for interim } \\
\text { storage and emplacement in the HLW geologic } \\
\text { repository. }\end{array}$ \\
\hline ITRU Waste for Storage & $\begin{array}{l}\text { ITRU sealed in containers suitable for interim } \\
\text { storage and emplacement in WIPP/geologic } \\
\text { repository (as required). }\end{array}$ \\
\hline Immobilized HLW & $\begin{array}{l}\text { Sealed containers of immobilized HLW derived from } \\
\text { treatment of tank wastes (e.g., existing and new } \\
\text { tank wastes). The containers of IHLW are placed in } \\
\text { a transport cask, that is loaded onto a transport } \\
\text { vehicle. At the time of shipment the waste will be } \\
\text { certified to meet repository acceptance } \\
\text { requirements. }\end{array}$ \\
\hline Immobilized TRU Waste & $\begin{array}{l}\text { Solidified TRU waste sealed in containers, with } \\
\text { required characterization information, and transport } \\
\text { casks along with the transport vehicle delivered to } \\
\text { the designated WIPP Site Facility. }\end{array}$ \\
\hline Immoblilized LLW & (Interim product of 4.2.3.1) \\
\hline In-Process Waste & $\begin{array}{l}\text { Pretreated HLW, pretreated TRU tank waste, } \\
\text { pretreated LLW and partially pretreated waste, with } \\
\text { required characterization information, suitable for } \\
\text { transfer to Manage Tank Waste (4.2.1) function. }\end{array}$ \\
\hline Infrastructure Support & $\begin{array}{l}\text { Basic, commonly used goods and services provided } \\
\text { to multiple functions to sustain their operations. }\end{array}$ \\
\hline Initial disposal facility & $\begin{array}{l}\text { Disposal facility buildings, rail facilities, equipment } \\
\text { and initial disposal cell capacity ready to accept } \\
\text { waste material }\end{array}$ \\
\hline
\end{tabular}


TABLE 2-1 Product Descriptions (Continued)

\begin{tabular}{|l|l|}
\hline Product & Description \\
\hline Institutional Information & $\begin{array}{l}\text { Institutional information provided to the regulators } \\
\text { concerning planning, progress, and priority actions. }\end{array}$ \\
\hline Interim Stored IHLW & (Interim product of 4.2.2.4) \\
\hline Interim Stored ITRU Waste & (Interim product of 4.2.2.5) \\
\hline Interim Stored Overpacked Capsules & (Interim product of 4.2.2.4) \\
\hline LLMW/LLW & Low level waste and low level mixed waste. \\
\hline Laboratory Waste from Characterization & $\begin{array}{l}\text { Liquid and slurry wastes generated by the } \\
\text { laboratories during handling, preparation, and } \\
\text { analysis of MTW Characterization Samples. This } \\
\text { waste also includes excess samples that are } \\
\text { disposed of by the laboratory. These wastes are } \\
\text { collected and transfered to DST's and Liquid SW for } \\
\text { Storage from the MSGW \& EF function. }\end{array}$ \\
\hline Landfill Wastes & $\begin{array}{l}\text { Waste suitable for disposition in a landfill. Does not } \\
\text { include solid, tank, or effluent waste. }\end{array}$ \\
\hline Legacy Solid Waste & $\begin{array}{l}\text { It is existing waste resulting from Hanford's defense } \\
\text { material production and energy production } \\
\text { missions. }\end{array}$ \\
\hline Less Dependent Local Economy & $\begin{array}{l}\text { Resources used during cleanup have provided } \\
\text { secondary benefits to enhance the economic } \\
\text { viability of the regional economy. }\end{array}$ \\
\hline Liquid Effluent from DGE & $\begin{array}{l}\text { Residues, cleaning wastes, and other liquid or } \\
\text { slury wastes originating from the removal of } \\
\text { chemical inventories and decontamination of } \\
\text { excess facilities. }\end{array}$ \\
\hline Liquid Effluent from DEF & $\begin{array}{l}\text { Includes all liquid streams generated from } \\
\text { condensation, scrubbing, and filtration of off-gas } \\
\text { streams. }\end{array}$ \\
\hline $\begin{array}{l}\text { Liquid effluent that requires disposal (not reusable) } \\
\text { and is generated as a byproduct from treatment or } \\
\text { interim storage of DRM. }\end{array}$ \\
\hline $\begin{array}{l}\text { Liquid waste generated from functions associated } \\
\text { with immobilization and disposition of low-level tank } \\
\text { waste. }\end{array}$ \\
\hline
\end{tabular}


TABLE 2-1 Product Descriptions (Continued)

\begin{tabular}{|c|c|}
\hline Product & Description \\
\hline Liquid SW for Storage & $\begin{array}{l}\text { Liquid secondary waste for storage, with required } \\
\text { characterization information, produced in the } \\
\text { MSGW \& EF (4.2.3) function. This includes } \\
\text { cleaning waste, lab waste from sample } \\
\text { characterization, but no packaged waste. }\end{array}$ \\
\hline $\begin{array}{l}\text { Liquid Wastes and Documentation Generated } \\
\text { During AW Cleanup }\end{array}$ & $\begin{array}{l}\text { All liquid waste that meets the acceptance criteria of } \\
\text { the Manage Aqueous Wastes function. Includes } \\
\text { liquid wastes with low level radioactive and } \\
\text { hazardous contamination levels and required } \\
\text { documentation. }\end{array}$ \\
\hline Low Level SW & $\begin{array}{l}\text { Secondary LLW for immobilization. This includes } \\
\text { LLW glass material separated from container } \\
\text { decontamination waste, off-standard glass requiring } \\
\text { rework, glass spillage, glass from radioactive melter } \\
\text { tests, and glass removed from failed melters. Scrap } \\
\text { glass is fed directly back into the Immobilize \& } \\
\text { Dispose LLW function. }\end{array}$ \\
\hline MTW SG Gaseous Waste & $\begin{array}{l}\text { Radioactive and mixed gaseous waste generated } \\
\text { by the Manage Tank Waste function that requires } \\
\text { treatment prior to discharging to the environment. }\end{array}$ \\
\hline MTW SG Liquid Effluent & $\begin{array}{l}\text { Liquids generated during the operation of } \\
\text { equipment and systems that are or may be } \\
\text { contaminated with trace amounts of hazardous or } \\
\text { radioactive components and as minimum require } \\
\text { monitoring to insure regulatory compliance. } \\
\text { Included are liquids discharged from single pass } \\
\text { cooling systems, and steam and process } \\
\text { condensate generated from the concentrate } \\
\text { function. Low level liquid waste generated by any } \\
\text { process will be treated as tank waste. }\end{array}$ \\
\hline MTW SG Solid Waste & $\begin{array}{l}\text { Solid waste generated from functions associated } \\
\text { with managing tank waste. }\end{array}$ \\
\hline
\end{tabular}


TABLE 2-1 Product Descriptions (Continued)

\begin{tabular}{|c|c|}
\hline Product & Description \\
\hline MTW SGW \& EF & $\begin{array}{l}\text { All excess facilities and wastes, with required } \\
\text { characterization information, generated during } \\
\text { MTW activities except that portion that will be } \\
\text { processed into Immobilized High-Level Waste } \\
\text { (IHLW), Immobilized TRU Waste (ITRU), or } \\
\text { Immobilized Low-Level Tank Waste (ILLTW). This } \\
\text { includes equipment and facilities that have fulfilled } \\
\text { their purpose but are now available for appropriate } \\
\text { reuse or final disposition: mixed, hazardous, or } \\
\text { radiological waste in liquid or solid form (including } \\
\text { spent samples) being returned from laboratories } \\
\text { that originated in the MTW function, and all } \\
\text { nonradioactive, nonhazardous liquid and solid } \\
\text { effluent. Also included in the tank waste is the } \\
\text { following nonprocess solid waste: fallen equipment, } \\
\text { severed pipes, lead bricks, cobalt slugs, fuel pin } \\
\text { elements, etc. }\end{array}$ \\
\hline Mission Essential Capabilities & $\begin{array}{l}\text { Mission essential capabilities in the form of all } \\
\text { physical resources, manpower, technology, } \\
\text { infrastructure, expertise required by all the other } \\
\text { functions to conduct their submissions. }\end{array}$ \\
\hline Mission Requirements & $\begin{array}{l}\text { Externally- and internally-imposed product } \\
\text { specifications and process constraints derived from } \\
\text { all applicable laws, directives, policies, standards, } \\
\text { agreements with stakeholders, engineering studies, } \\
\text { safety analyses, and findings from surveillances } \\
\text { and audits. }\end{array}$ \\
\hline
\end{tabular}


TABLE 2-1 Product Descriptions (Continued)

\begin{tabular}{|c|c|}
\hline Product & Description \\
\hline New Tank Waste & $\begin{array}{l}\text { New waste, with required characterization } \\
\text { information, addded to the DSTs from activities } \\
\text { conducted to Deactivate Facilities (4.1), Remedy } \\
\text { Solid Waste (4.3), Remedy/Restore Sites, Facilities } \\
\text { and Ground Water (4.4), Manage Aqueous Waste } \\
\text { (4.5), Correct Infrastructure Deficiencies (4.6), and } \\
\text { Store, Treat and Disposition SNM/NM/NF Materials } \\
\text { (4.7) (as defined in WHC-EP-0722, Systems } \\
\text { Engineering Functions and Requirements for the } \\
\text { Hanford Cleanup Mission: First Issue, draft } \\
\text { December 1993, J. J. Holmes). Waste will be } \\
\text { conditioned by the generator to meet the } \\
\text { acceptance criteria of the Remediate Tank Waste } \\
\text { function prior to acceptance. }\end{array}$ \\
\hline Non-Compliant Effluent \& Documentation & $\begin{array}{l}\text { The effluent of the aqueous waste treatment which } \\
\text { is non-compliant and may need further treatment. }\end{array}$ \\
\hline Non-Issue Information & $\begin{array}{l}\text { Information released to the public for general } \\
\text { knowledge. }\end{array}$ \\
\hline Off-site Certified Solid Waste & $\begin{array}{l}\text { This is solid waste that meets the certification } \\
\text { requirements that allow off-site disposition. }\end{array}$ \\
\hline On-site Certified Solid Waste & $\begin{array}{l}\text { This is solid waste that meets the certification } \\
\text { requirements that allow on-site disposition. }\end{array}$ \\
\hline OverPacked Capsules & $\begin{array}{l}\text { Cesium and strontium capsules placed in an } \\
\text { overpack container and certified for transfer to the } \\
\text { HLW repository. }\end{array}$ \\
\hline Overpacked Cs/Sr Capsules for Storage/Disposal & $\begin{array}{l}\text { Cs/Sr capsules in containers/canisters suitable for } \\
\text { interim storage and long term disposal offsite. }\end{array}$ \\
\hline PW SG Gaseous Waste & $\begin{array}{l}\text { Gaseous waste, with required characterization } \\
\text { information, generated from functions associated } \\
\text { with processing tank waste. }\end{array}$ \\
\hline PW SG Liquid Effluent & $\begin{array}{l}\text { Liquid waste, with required characterization } \\
\text { information, generated from functions associated } \\
\text { with processing tank waste. }\end{array}$ \\
\hline PW SG Solid Waste & $\begin{array}{l}\text { Solid waste, with required characterization } \\
\text { information, generated from functions associated } \\
\text { with processing tank waste. }\end{array}$ \\
\hline
\end{tabular}


TABLE 2-1 Product Descriptions (Continued)

\begin{tabular}{|l|l|}
\hline Product & Description \\
\hline PW SGW \& EF & $\begin{array}{l}\text { Excess facilities with waste and miscellaneous } \\
\text { wastes generated from processing of tank waste. } \\
\text { a.Excess Facilities for PW } \\
\text { Facilities fulfilling their purpose but are now } \\
\text { available for appropriate reuse, following cleaning. } \\
\text { b.Miscellaneous Wastes } \\
\text { Any mixed or radioactive waste, industrial waste, } \\
\text { gaseous waste,TRU solid waste, dangerous waste, } \\
\text { uranium, chemicals, liquid effluents, or sanitary } \\
\text { waste, requiring conditioning by the Manage } \\
\text { System Generated Waste and Excess Facilities } \\
\text { function prior to transfer to appropriate interface for } \\
\text { reuse or final disposition. }\end{array}$ \\
\hline Packaged Solid Waste & $\begin{array}{l}\text { This is solid waste that meets the certification } \\
\text { requirements that allow on-site disposition. }\end{array}$ \\
\hline Pretreated HLW for Immobilization & $\begin{array}{l}\text { Pretreated HLW, with required characterization } \\
\text { information, blended and/or concentrated to final } \\
\text { composition meeting specifications for feed to } \\
\text { immobilization. }\end{array}$ \\
\hline Pretreated LLW for Immobilization & $\begin{array}{l}\text { Tank waste that meets the LLW feed specifications } \\
\text { for feed to the LLW immobilization process. }\end{array}$ \\
\hline Pretreated TRU Waste for Immobilization & $\begin{array}{l}\text { Pretreated TRU Tank Waste, with required } \\
\text { characterization information, blended and/or } \\
\text { concentrated to final composition meeting } \\
\text { specifications for feed to immobilization. }\end{array}$ \\
\hline Processed Post-70 TRU/TRUM & $\begin{array}{l}\text { Transuranic waste and transuranic mixed waste } \\
\text { processed after 1970 resulting from cleanup of } \\
\text { facilities or sites. }\end{array}$ \\
\hline $\begin{array}{l}\text { Public trust and acceptance is obtained. } \\
\text { A prerequisite for successful completion of the } \\
\text { cleanup mission is obtaining public trust. This trust } \\
\text { is essential to gaining the broad public acceptance } \\
\text { needed to close the site. Embedded in this end } \\
\text { state is the information supplied to the public on } \\
\text { progress, planning, and unusual events during } \\
\text { mission implementation. }\end{array}$ \\
\hline
\end{tabular}


TABLE 2-1 Product Descriptions (Continued)

\begin{tabular}{|l|l|}
\hline Product & Description \\
\hline Public Group Specific PI Plan & $\begin{array}{l}\text { The public involvement plan for identifying and } \\
\text { developing or obtaining information necessary to } \\
\text { alleviate public concerns, for providing the } \\
\text { information to the public, and reconciling } \\
\text { differences between the public and site needs and } \\
\text { expectations. }\end{array}$ \\
\hline Public Information & $\begin{array}{l}\text { Public information to entities outside the mission } \\
\text { consisting of press releases, position papers, } \\
\text { educational matter, policy, strategy, etc. }\end{array}$ \\
\hline Public Needs/Information & $\begin{array}{l}\text { In the course of acquiring public trust and } \\
\text { acceptance, needs and information may be } \\
\text { discovered which may impact direction \& control, } \\
\text { mission requirements, and defined work packages. } \\
\text { This information must be fed back to the MANAGE } \\
\text { PROGRAM function for evaluation. }\end{array}$ \\
\hline Public Values & $\begin{array}{l}\text { Public values to the program planning process from } \\
\text { the OBTAIN PUBLIC ACCEPTANCE function. }\end{array}$ \\
\hline Quality Assurance Solid Waste Samples & $\begin{array}{l}\text { This is solid waste treatment process quality } \\
\text { samples used to certify that the treated waste } \\
\text { product meets the solid waste disposition } \\
\text { requirements. }\end{array}$ \\
\hline Received Aqueous Waste and Documentation & $\begin{array}{l}\text { RA excavation sites that have undergone remedial } \\
\text { action and are cleaned up to acceptable levels for } \\
\text { intended land use. }\end{array}$ \\
\hline RA area sites cleaned up & $\begin{array}{l}\text { Aqueous waste and associated descriptive } \\
\text { documentation containing low level radioactive and } \\
\text { hazardous contamination levels. }\end{array}$ \\
\hline Received Solid Waste & $\begin{array}{l}\text { This is solid waste received from solid waste } \\
\text { operations, cleanup operations, and other missions, } \\
\text { including removed legacy waste, that is now ready } \\
\text { for disposition. }\end{array}$ \\
\hline TRU/TRUM removed and covered to RCRA \\
\hline
\end{tabular}


TABLE 2-1 Product Descriptions (Continued)

\begin{tabular}{|c|c|}
\hline Product & Description \\
\hline Recycled Containers and Transporters & $\begin{array}{l}\text { Transporter and shipping containers suitable for } \\
\text { reuse. }\end{array}$ \\
\hline Releasable Liquid from Aqueous Waste & $\begin{array}{l}\text { Liquids cleaned to standards acceptable for release } \\
\text { to the environment. }\end{array}$ \\
\hline Released Effluents & $\begin{array}{l}\text { Fluids and gases resulting from Hanford Cleanup } \\
\text { operations that are released to the environment or } \\
\text { site aquifer. }\end{array}$ \\
\hline Released Gaseous Effluents & $\begin{array}{l}\text { Gaseous effluents resulting from Hanford Cleanup } \\
\text { operations that are released to the atmosphere. }\end{array}$ \\
\hline Released Liquid Effluents & $\begin{array}{l}\text { Liquid effluents resulting from Hanford Cleanup } \\
\text { operations that are released into the environment. }\end{array}$ \\
\hline Released Liquid Effluents from R\&R & $\begin{array}{l}\text { Liquid effluents resulting from remedy and restore } \\
\text { activities released to the environment or into the } \\
\text { site aquifer. }\end{array}$ \\
\hline Remediated Aquifer & $\begin{array}{l}\text { Aquifer that has undergone remedial action to attain } \\
\text { acceptable levels of water quality utilizing various } \\
\text { methods of containment and/or treatment. }\end{array}$ \\
\hline Resource In Need Of Maintenance & $\begin{array}{l}\text { Operational infrastructure resources requiring } \\
\text { maintenance. }\end{array}$ \\
\hline Resource Transition Needs/Information & $\begin{array}{l}\text { Program formulation, progress, evaluation, and } \\
\text { resource requirements information }\end{array}$ \\
\hline Resources Redirected for Mission & $\begin{array}{l}\text { Resources released from current Hanford use and } \\
\text { reassigned for use in the Hanford clean-up mission. }\end{array}$ \\
\hline Resources Transferred & $\begin{array}{l}\text { Land and other resources transferred for external } \\
\text { socially beneficial uses. } \\
\text { Land and other resources recovered and returned } \\
\text { for beneficial uses by the Hanford Cleanup Program } \\
\text { (e.g., caretaker, dual use infrastructure, and other } \\
\text { Hanford Site missions). }\end{array}$ \\
\hline Retrieved Cesium/Strontium Capsules & $\begin{array}{l}\text { Cesium and strontium capsules removed from } \\
\text { storage to initiate transfer to the Process Waste } \\
\text { function for final disposition. }\end{array}$ \\
\hline
\end{tabular}


TABLE 2-1 Product Descriptions (Continued)

\begin{tabular}{|c|c|}
\hline Product & Description \\
\hline Retrieved Solid Waste & $\begin{array}{l}\text { Solid waste that has been received or retrieved and } \\
\text { is ready for disposition. }\end{array}$ \\
\hline Retrieved Tank Waste & $\begin{array}{l}\text { Waste removed from underground storage tanks } \\
\text { (DSTs, SSTs, and miscellaneous tanks) with } \\
\text { required characterization information, that will } \\
\text { ultimately be processed by the IHLW, ITRU, or } \\
\text { ILLW functions and is ready for transfer to other } \\
\text { facilities. }\end{array}$ \\
\hline Reusable Facilities & $\begin{array}{l}\text { Excess facilities, excluding tanks, that have } \\
\text { reached their useful life and have no currently } \\
\text { identifiable or planned programmatic use in TWRS. } \\
\text { These facilities may be used at the site-level to } \\
\text { support SST and DST closure activities. }\end{array}$ \\
\hline Reusable Liquid from Aqueous Waste & $\begin{array}{l}\text { Liquid from aqueous waste processing that can be } \\
\text { reused by on-site systems. }\end{array}$ \\
\hline Reusable Liquid from DLE & $\begin{array}{l}\text { Process condensates and environmentally } \\
\text { dischargeable liquids suitable for reuse. }\end{array}$ \\
\hline Reusable Materials for MSGW \& EF & $\begin{array}{l}\text { Materials that can be reused or recycled by other } \\
\text { MSGW \& EF functions. }\end{array}$ \\
\hline Reusable Materials for MTW & $\begin{array}{l}\text { Equipment, chemicals (including water), or facilities } \\
\text { that have fulfilled their original purpose and are now } \\
\text { available and appropriate for use by Manage Waste } \\
\text { Tank function. }\end{array}$ \\
\hline Reusable Materials for PW & $\begin{array}{l}\text { Equipment, chemicals (including water), or facilities } \\
\text { that have fulfilled their original purpose and are now } \\
\text { available and appropriate for use by Process Waste } \\
\text { function. }\end{array}$ \\
\hline Reusable Materials for Site & $\begin{array}{l}\text { Equipment, chemicals (including water), that have } \\
\text { fulfilled their original purpose and are now available } \\
\text { and appropriate for use by non-TWRS, site-level } \\
\text { functions. }\end{array}$ \\
\hline Reusable Solids from DSW & $\begin{array}{l}\text { Solid materials segregated from solid waste that } \\
\text { can be beneficially reused or recycled. }\end{array}$ \\
\hline SNM/NM/NF Dispositioned Off Site & SNM, NM, and NF shipped off site. \\
\hline
\end{tabular}


TABLE 2-1 Product Descriptions (Continued)

\begin{tabular}{|c|c|}
\hline Product & Description \\
\hline $\begin{array}{l}\text { SNM/NM/NF Materials Transferred To Beneficial } \\
\text { Uses }\end{array}$ & $\begin{array}{l}\text { Nuclear material that is recovered during facility } \\
\text { deactivation and transferred to the public or private } \\
\text { domains. }\end{array}$ \\
\hline SNM/NM/NF Materials for Disposition & $\begin{array}{l}\text { SNM/NM/NF materials that are being transfer from } \\
\text { storage for disposition. These materials may } \\
\text { require further treatment prior to transfer to final } \\
\text { disposition. }\end{array}$ \\
\hline SNM/NM/NF Recovered from Deactivation & $\begin{array}{l}\text { SNM/NM/NF removed from a facility in order to } \\
\text { place it in a deactivated state. }\end{array}$ \\
\hline SW for Processing & $\begin{array}{l}\text { Secondary waste for processing consists of scrap } \\
\text { glass (e.g., glass recovered from failed melters), } \\
\text { and TRU tank solids scrap, with required } \\
\text { characterization information for both. Scrap glass } \\
\text { and TRU tank solids scrap can be fed directly back } \\
\text { to the immobilization function. }\end{array}$ \\
\hline SW from Immobilize \& Dispose LLW & $\begin{array}{l}\text { This material will consist of processing wastes, } \\
\text { typically fluids, and out of specification immobilized } \\
\text { and/or recovered immobilized tank wastes requiring } \\
\text { additional treatment as a result of pending "leave or } \\
\text { retrieve for additional treatment" decisions. This } \\
\text { material will consist of any treated waste not } \\
\text { meeting acceptance requirements and any material } \\
\text { retrieved for further processing. }\end{array}$ \\
\hline Safe and Compliant Resources (Type 1) & $\begin{array}{l}\text { All necessary resources for safe and compliant } \\
\text { operation of type } 1 \text { facilities in accordance with } \\
\text { governing safety codes and regulations. }\end{array}$ \\
\hline Safe and Compliant Resources (Type 2) & $\begin{array}{l}\text { All necessary resources for safe and compliant } \\
\text { operation of type } 2 \text { facilities in accordance with } \\
\text { governing safety codes and regulations. }\end{array}$ \\
\hline Safe and Compliant Resources (Type 3) & $\begin{array}{l}\text { All necessary resources for safe and compliant } \\
\text { operation of type } 3 \text { facilities in accordance with } \\
\text { governing safety codes and regulations. }\end{array}$ \\
\hline Safe and Compliant Resources (Type 4) & $\begin{array}{l}\text { All necessary resources for safe and compliant } \\
\text { operation of type } 4 \text { facilities in accordance with } \\
\text { governing safety codes and regulations. }\end{array}$ \\
\hline
\end{tabular}


TABLE 2-1 Product Descriptions (Continued)

\begin{tabular}{|l|l|}
\hline Product & Description \\
\hline $\begin{array}{l}\text { Samples of Waste Requiring Additional } \\
\text { Characterization }\end{array}$ & $\begin{array}{l}\text { Solid waste that needs additional characterization } \\
\text { data before final disposition can be made. }\end{array}$ \\
\hline Sanitary Landfill Waste & $\begin{array}{l}\text { Waste materials other than those containing } \\
\text { radioactive, TRU, hazardous, or sanitary sewage. }\end{array}$ \\
\hline Sanitary Sewage & Refuse liquids or waste matter generated on site. \\
\hline Secondary Wastes And Documentation & $\begin{array}{l}\text { The secondary wastes generated from aqueous } \\
\text { waste treatment and the associated documentation. }\end{array}$ \\
\hline Solid Waste Archive Samples & $\begin{array}{l}\text { Solid waste samples retrieved from archival storage } \\
\text { for further analysis. }\end{array}$ \\
\hline Solid Waste From Other Missions & $\begin{array}{l}\text { Solid waste that comes from other DOE missions } \\
\text { outside of the Hanford Cleanup Mission. }\end{array}$ \\
\hline Solid Waste Generated During Solid Waste & $\begin{array}{l}\text { Contaminated tools, equipment and materials } \\
\text { generated as a direct result of cleanup operations; } \\
\text { including used cleaning solvents, rags, stack filters } \\
\text { and similar items requiring processing prior to } \\
\text { disposal or transfer to a useful function within or } \\
\text { outside the Cleanup Hanford mission }\end{array}$ \\
\hline Solid Waste Samples & $\begin{array}{l}\text { Solid waste samples that were used to analyze the } \\
\text { waste inventory that now require archiving. }\end{array}$ \\
\hline Solid Waste from Aqueous Waste Processing & $\begin{array}{l}\text { Solid waste generated from functions associated } \\
\text { with processing aqueous waste. }\end{array}$ \\
\hline Solid Waste from DEF & $\begin{array}{l}\text { Solid waste generated from removal of hazardous } \\
\text { and radioactive inventories and decontamination of } \\
\text { excess facilities. }\end{array}$ \\
\hline Solid Waste from DGE & $\begin{array}{l}\text { Solid waste from DGE includes wastes generated } \\
\text { from excess filters, particulates, etc. generated from } \\
\text { off-gas stream treatment and disposition. }\end{array}$ \\
\hline $\begin{array}{l}\text { Solid wastes generated by condensate treatment } \\
\text { processes. This stream may include ion exchange } \\
\text { resins, precipitated sludges, and ammonium sulfate } \\
\text { salts from waste neutralization. Failed process } \\
\text { equipment and expended support equipment (i.e., } \\
\text { HEPA filters) will be included in this stream. }\end{array}$ \\
\hline
\end{tabular}


TABLE 2-1 Product Descriptions (Continued)

\begin{tabular}{|l|l|}
\hline Product & Description \\
\hline Solid Waste from DRM & $\begin{array}{l}\text { Solid waste that requires disposal (not reusable) } \\
\text { and is generated as a byproduct from treatment or } \\
\text { interim storage of DRM. }\end{array}$ \\
\hline Solid Waste from Deactivation & $\begin{array}{l}\text { Solid waste materials contaminated with radioactive } \\
\text { or hazardous materials resulting from deactivating } \\
\text { the facility and from maintaining the facility prior to } \\
\text { deactivation and until demolition or transfer. }\end{array}$ \\
\hline Solid Waste from Deactivation (Type 1) & $\begin{array}{l}\text { Solid waste materials contaminated with radioactive } \\
\text { or hazardous materials resulting from deactivating } \\
\text { the type 1 facility and from maintaining the facility } \\
\text { prior to deactivation and until demolition or transfer. }\end{array}$ \\
\hline Solid Waste from Deactivation (Type 2) & $\begin{array}{l}\text { Solid waste materials contaminated with radioactive } \\
\text { or hazardous materials resulting from deactivating } \\
\text { the type } 2 \text { facility and from maintaining the facility } \\
\text { prior to deactivation and until demolition or transfer. }\end{array}$ \\
\hline Solid Waste from Deactivation (Type 3) & $\begin{array}{l}\text { Solid waste materials contaminated with radioactive } \\
\text { or hazardous materials resulting from deactivating } \\
\text { the type } 3 \text { facility and from maintaining the facility } \\
\text { prior to deactivation and until demolition or transfer. }\end{array}$ \\
\hline Solid Waste from ILLW & $\begin{array}{l}\text { Solid waste generated from functions associated } \\
\text { with immobilization and disposition of low-level tank } \\
\text { waste. }\end{array}$ \\
\hline Solid Waste from Infrastructure & $\begin{array}{l}\text { Solid waste materials contaminated with radioactive } \\
\text { or hazardous materials resulting from correcting } \\
\text { unsafe or non-compliant conditions or from } \\
\text { operation of Hanford Cleanup mission infrastructure } \\
\text { systems. }\end{array}$ \\
\hline $\begin{array}{l}\text { Solid waste resulting from functions associated with } \\
\text { site remediation and restoration. }\end{array}$ \\
\hline $\begin{array}{l}\text { Radioactive or hazardous material or solid objects } \\
\text { from the cleanup of SNM/NM/NF materials. }\end{array}$ \\
\hline
\end{tabular}


TABLE 2-1 Product Descriptions (Continued)

\begin{tabular}{|c|c|}
\hline Product & Description \\
\hline Solid Waste from Tank Waste Remediation & $\begin{array}{l}\text { Dispositioned solid waste includes all packaged } \\
\text { solid waste that meets acceptance criteria of } \\
\text { Remediate Solid Waste function. Includes } \\
\text { hazardous, mixed and radioactive wastes, minus } \\
\text { any scrap glass that is fed back into the IHLW } \\
\text { process. }\end{array}$ \\
\hline $\begin{array}{l}\text { Solid Wastes and Documentation Generated During } \\
\text { AW Cleanup }\end{array}$ & $\begin{array}{l}\text { Radioactive or hazardous material or solid objects } \\
\text { from the cleanup of Aqueous Wastes. }\end{array}$ \\
\hline Stabilized Type 1 Facility & $\begin{array}{l}\text { Type } 1 \text { facility with initial stabilization or preparation } \\
\text { activities involving SNM/NM/NF materials and } \\
\text { radioactive waste. }\end{array}$ \\
\hline Stabilized Type 2 Facility & Type 2 facility with stabilized radioactive materials. \\
\hline Stabilized Type 3 Facility & Type 3 facility with stabilized hazardous material. \\
\hline System Architecture & $\begin{array}{l}\text { System design (architecture) is the set of activities } \\
\text { which selects the solution concept and formulates a } \\
\text { system description suitable for implementing and/or } \\
\text { procuring a system (that will achieve the Hanford } \\
\text { cleanup mission). }\end{array}$ \\
\hline System Functional Definition & $\begin{array}{l}\text { An identification of the functions that must be } \\
\text { performed to achieve the Hanford cleanup mission. }\end{array}$ \\
\hline System Requirements & $\begin{array}{l}\text { An identification of the set of activities neceassary } \\
\text { to determine how well a function must be performed } \\
\text { and under what conditions it must be performed. }\end{array}$ \\
\hline Tank Waste for Pretreatment & $\begin{array}{l}\text { Tank waste to be pretreated. This includes partially } \\
\text { pretreated waste and untreated waste. }\end{array}$ \\
\hline Tank Waste for Retrieval & $\begin{array}{l}\text { Wastes stored in underground storage tanks } \\
\text { (DSTs, SSTs, and miscellaneous tanks). }\end{array}$ \\
\hline Tank Waste for Sampling & $\begin{array}{l}\text { Solid, liquid, and gaseous substances residing } \\
\text { within the Store Waste function that have been } \\
\text { identified for characterization requiring laboratory or } \\
\text { in situ analysis. }\end{array}$ \\
\hline Tank Waste from Aqueous Waste Processing & $\begin{array}{l}\text { Tank waste materials resulting from processing of } \\
\text { aqueous waste containing a high level of hazardous } \\
\text { or mixed waste. }\end{array}$ \\
\hline
\end{tabular}


TABLE 2-1 Product Descriptions (Continued)

\begin{tabular}{|l|l|}
\hline Product & Description \\
\hline Tank Waste from Deactivation & $\begin{array}{l}\text { Tank waste materials resulting from deactivation of } \\
\text { facilities containing a high level of hazardous or } \\
\text { mixed waste. }\end{array}$ \\
\hline Tank Waste from Deactivation (Type 1) & $\begin{array}{l}\text { Tank waste materials resulting from deactivation of } \\
\text { type } 1 \text { facilities containing a high level of hazardous } \\
\text { or mixed waste. }\end{array}$ \\
\hline Tank Waste from Deactivation (Type 2) & $\begin{array}{l}\text { Tank waste materials resulting from deactivation of } \\
\text { type 2 facilities containing a high level of hazardous } \\
\text { or mixed waste. }\end{array}$ \\
\hline Tank Waste from Remedy/Restore & $\begin{array}{l}\text { Tank waste materials resulting from remediation } \\
\text { and restoration of sites containing a high level of } \\
\text { hazardous or mixed waste. }\end{array}$ \\
\hline Tank Waste from SNM/NM/NF Cleanup & $\begin{array}{l}\text { Tank waste resulting from the cleanup of } \\
\text { SNM/NM/NF containing a high level of radioactive, } \\
\text { hazardous, or mixed waste. }\end{array}$ \\
\hline Tank Waste from Solid Waste Cleanup & $\begin{array}{l}\text { Tank waste materials resulting from cleanup of solid } \\
\text { waste items containing a high level of hazardous or } \\
\text { mixed waste. }\end{array}$ \\
\hline Transfer Agreement & $\begin{array}{l}\text { Transfer Agreements consisting of identification of } \\
\text { resources to be used in building the local economy } \\
\text { which essentially causes transferrable items to be } \\
\text { removed from the "disposal" list to the transfer list. }\end{array}$ \\
\hline Transferrable Resources from (Type 2) & Any item having a new owner identified. \\
\hline Transferrable Resources & $\begin{array}{l}\text { Equipment, components, or materials from } \\
\text { deactivation of Type } 1 \text { facilities cleaned up to } \\
\text { acceptable levels and having a new owner } \\
\text { identified. }\end{array}$ \\
\hline $\begin{array}{l}\text { Transferrable Resources from (Type 1) } \\
\text { Deactivation }\end{array}$ & $\begin{array}{l}\text { Equipment, components, or materials from } \\
\text { deactivation of Type 2 facilities cleaned up to } \\
\text { acceptable levels and having a new owner } \\
\text { identified. }\end{array}$ \\
\hline Deactivation & $\begin{array}{l}\text { Equipment, components, or materials from } \\
\text { deactivation of Type } 3 \text { facilities cleaned up to } \\
\text { acceptable levels and having a new owner } \\
\text { identified. }\end{array}$ \\
\hline &
\end{tabular}


TABLE 2-1 Product Descriptions (Continued)

\begin{tabular}{|l|l|}
\hline Product & Description \\
\hline $\begin{array}{l}\text { Transferrable Resources from (Type 4) } \\
\text { Deactivation }\end{array}$ & $\begin{array}{l}\text { Equipment, components, or materials from } \\
\text { deactivation of Type 4 facilities cleaned up to } \\
\text { acceptable levels and having a new owner } \\
\text { identified. }\end{array}$ \\
\hline Transferrable Resources from Aqueous Waste & $\begin{array}{l}\text { Equipment, components, or materials from aqueous } \\
\text { waste processing cleaned up to acceptable levels } \\
\text { and having a new owner identified. }\end{array}$ \\
\hline Transferrable Resources from Deactivation & $\begin{array}{l}\text { Equipment, components, or materials from } \\
\text { deactivation cleaned up to acceptable levels and } \\
\text { having a new owner identified. }\end{array}$ \\
\hline Transferrable Resources from Infrastructure & $\begin{array}{l}\text { Equipment, components, or materials resulting from } \\
\text { correcting unsafe or non-compliant infrastructure } \\
\text { conditions, cleaned up to acceptable levels and } \\
\text { having a new owner identified. }\end{array}$ \\
\hline Transferrable Resources from Remedy/Restore & $\begin{array}{l}\text { Equipment, components, or materials resulting from } \\
\text { site remediation and restoration cleaned up to } \\
\text { acceptable levels and having a new owner } \\
\text { identified. }\end{array}$ \\
\hline Transferrable Resources from SNM/NM/NF & $\begin{array}{l}\text { Equipment, components, and materials from } \\
\text { SNM/NM/NF treatment, storage and disposal } \\
\text { cleaned up to acceptable levels and having a new } \\
\text { owner or user identified. }\end{array}$ \\
\hline Cleanup & $\begin{array}{l}\text { Equipment or components cleaned up to } \\
\text { acceptable levels and having a new owner } \\
\text { identified. }\end{array}$ \\
\hline Transferrable Resources from Solid Waste & $\begin{array}{l}\text { Equipment, components, or materials resulting from } \\
\text { tank waste remediation cleaned up to acceptable } \\
\text { levels and having a new owner identified. }\end{array}$ \\
\hline Remediation & $\begin{array}{l}\text { Technologies that are transferrable for uses outside } \\
\text { of the Hanford clean-up mission after } \\
\text { modifications/upgrades are completed to make the } \\
\text { technology useable outside of the Hanford clean-up } \\
\text { mission. }\end{array}$ \\
\hline & $\begin{array}{l}\text { Trable Technology } \\
\text { Tank Waste }\end{array}$ \\
\hline
\end{tabular}


TABLE 2-1 Product Descriptions (Continued)

\begin{tabular}{|l|l|}
\hline Product & Description \\
\hline Transitioned Economy & $\begin{array}{l}\text { Resources (e.g., technology, people, expertise) } \\
\text { developed and used during cleanup have been } \\
\text { leveraged to enhance the economic viability of the } \\
\text { regional economy. } \\
\text { Cleanup resources will have been expended in a } \\
\text { manner to support independence of the } \\
\text { local/private sector economy. This can be achieved } \\
\text { through development of public/private sector } \\
\text { partnerships, transfer of technologies for use } \\
\text { elsewhere, etc. Also, expenditure of these } \\
\text { resources should, where possible, provide national } \\
\text { and international benefit by making technology and } \\
\text { expertise broadly available. }\end{array}$ \\
\hline Treated Effluent And Documentation & $\begin{array}{l}\text { The effluents resulting for aqueous waste treatment } \\
\text { along with required effluent data collected during } \\
\text { treatment. }\end{array}$ \\
\hline Treated Solid Waste & $\begin{array}{l}\text { This is solid waste that has been treated so that it } \\
\text { meets the disposition requirements and is ready for } \\
\text { packaging. }\end{array}$ \\
\hline Treatment, Storage, and Disposition & $\begin{array}{l}\text { Collection of top level waste related products. } \\
\text { (not currently a product) }\end{array}$ \\
\hline Untreated Aqueous Waste and Documentation & $\begin{array}{l}\text { The waste and documentation which needs no } \\
\text { treatment and is passed directly to Disposition } \\
\text { Aqueous Waste. }\end{array}$ \\
\hline
\end{tabular}


TABLE 2-1 Product Descriptions (Continued)

\begin{tabular}{|c|c|}
\hline Product & Description \\
\hline Waste Concentrate & $\begin{array}{l}\text { The concentrated product generated by removal of } \\
\text { excess moisture from tank waste using a vacuum } \\
\text { evaporator, and returned to the DST's. } \\
\text { The Evaporator can produce two products: (1) } \\
\text { double-shell slurry (DSS) and (2) DSSF. These } \\
\text { products are defined by their relationship to the } \\
\text { sodium-aluminate boundary. When this boundary is } \\
\text { crossed, aluminate solids (specifically } \\
\text { sodium-aluminate crystals) precipitate out of } \\
\text { solution and form DSS, the most concentrated } \\
\text { product the Evaporator can produce. Although } \\
\text { sodium-aluminate crystals represent only a small } \\
\text { percentage of the solids in DSS, they greatly } \\
\text { increase its viscosity (up to } 100 \text { cP) making it more } \\
\text { difficult to pump from DSTs once transferred from } \\
\text { the Evaporator. Although it has been produced in } \\
\text { the past, there currently are no plans to produce } \\
\text { DSS. Processing of complexed wastes and } \\
\text { phosphate wastes in the Evaporator requires more } \\
\text { characterization to identify the end product density, } \\
\text { temperature, and boiling point. Typically, these } \\
\text { wastes enter the concentrator as dilute feeds and } \\
\text { require multiple passes through the Evaporator to } \\
\text { achieve the desired product concentration. } \\
\text { Phosphate and complexed wastes cannot be } \\
\text { concentrated to a DSS product because these } \\
\text { wastes have very small or no dissolved aluminates. } \\
\text { The DSSF is defined as a slurry with a chemical } \\
\text { composition that is below the sodium-aluminate } \\
\text { boundary but that could be concentrated past the } \\
\text { sodium-aluminate boundary, with a single additional } \\
\text { pass through the Evaporator. In contrast to DSS, } \\
\text { the viscosity of SDDF typically ranges from } 20 \text { to } 40 \\
\text { cP. Double-shell slurry feed is the planned product } \\
\text { of the Evaporator. }\end{array}$ \\
\hline Waste Concentrate for Sampling & $\begin{array}{l}\text { Concentrated waste product of the Concentrate } \\
\text { Waste function that have been identified for } \\
\text { characterization requiring laboratory or in situ } \\
\text { analysis as required for process control. }\end{array}$ \\
\hline
\end{tabular}


TABLE 2-1 Product Descriptions (Continued)

\begin{tabular}{|c|c|}
\hline Product & Description \\
\hline Waste Concentration Feed for Sampling & $\begin{array}{l}\text { Liquid or slurry waste feed to the Concentrate } \\
\text { Waste function that have been identified for } \\
\text { characterization requiring laboratory or in situ } \\
\text { analysis as required for process control. }\end{array}$ \\
\hline Waste material (DD) & $\begin{array}{l}\text { Decontaminated and demolished retired surplus } \\
\text { facilities removed. }\end{array}$ \\
\hline Waste material (RA) & $\begin{array}{l}\text { Contaminated material generated from excavation } \\
\text { of RA sites. }\end{array}$ \\
\hline Waste to Storage & $\begin{array}{l}\text { Transferable waste, including supernates and } \\
\text { interstitial liquids from saltwell pumping, transferred } \\
\text { from one storage tank to another to provide } \\
\text { additional capacity for new waste entering the } \\
\text { Manage Tank Waste function or to mitigate or } \\
\text { resolve a safety issue. Also, includes waste } \\
\text { externally generated and introduced into the } \\
\text { Manage Tank Waste function requiring storage } \\
\text { prior to processing or disposal. The concentrate } \\
\text { created by the Concentrate Waste function is } \\
\text { returned to storage as Waste to Storage as well as } \\
\text { In-process wastes returned for the Process Waste } \\
\text { function. }\end{array}$ \\
\hline Waste/Materials Dispositioned Off-Site & $\begin{array}{l}\text { High level, hazardous, and TRU waste or } \\
\text { SNM/NM/NF transferred to external entities for } \\
\text { disposal or disposition. }\end{array}$ \\
\hline Waste/Materials Dispositioned On-Site & Low level waste disposed on the 200 area plateau. \\
\hline
\end{tabular}




\subsection{REFERENCES}

1. Holmes, J. J., et. a7., 1994, Systems Engineering Functions and Requirements for the Hanford Cleanup Mission: First Issue, WHC-EP-0722, Draft, Westinghouse Hanford Company, Richland, Washington.

2. Holmes, J. J., 1994, Architecture Synthesis Basis for the Hanford Cleanup Mission: First Issue, WHC-EP-0779, Draft, Westinghouse Hanford Company, Richland, Washington.

3. Holmes, J. J., et. al., 1994, Systems Engineering Product Description Report for the Hanford Cleanup Mission: First Issue, WHC-EP-0783, Draft, Westinghouse Hanford Company, Richland, Washington.

4. Garrison, H. L., et. a1., 1994, Fiscal Year 1995 Hanford Mission P1an, Volume 1, Site Guidance, DOE/RL-93-102, United States Department of Energy, Richland Operations Office, Richland, Washington. 
WHC-EP-0801

DISTRIBUTION

Number of copies

ONSITE

Westinghouse Hanford Company

W. T. Alumkal $\$ 7-85$

K. B. Bailey

M. S. Bensky

R. J. Bliss

H6-33

H6-33

R. R. Borisch

R3-50

M. K. Britton

R3-56

J. L. Collings

B4 -54

G. Cox

H6-33

R. E. Deichman

B5-32

J. C. Fulton

G3 -03

M. L. Grygiel

R3-85

R. M. Hadley

B1-58

K. L. Hladek

G1-56

J. J. Holmes

H5-33

J. 0. Honeyman

H6-33

G. W. Jackson

S7 -81

C. N. Krohn

H6-33

B. S. Kuntz

H6-33

D. P. Lund

B3-25

H. G. McGuire

R3-56

D. E. McKenney

B3 -63

S. K. Murdock

N3-10

D. H. Nyman

B3 -35

F. J. Orsag

G6-06

S. M. O'Toole

B1 -58

J. D. Schaffer

B2 -30

N1 -71

S. E. Seeman

J. M. Steffen

H6-33

J. D. Williams

N1 -47

J. C. Womack

H6-28

T. W. Woods

R3-85

Correspondence Control

H6-33

Central Files

A3-01

Information Release Administration

L8-04

(3) $\quad$ 8 -07 
WHC-EP-0801

DISTRIBUTION (Continued)

Number of copies

ONSITE

7

U. S. Department of Energy, Richland Operations office

A. J. Colburn

R. 0. Puthoff (w/o attachment)

A5-58

W. A. Rutherford

(5)

A5-10

A5-04

6

Pacific Northwest Laboratory

W. A. Hesser

J. A. Mahaffey

M. J. Simpson

$\mathrm{K} 8-10$

M. B. Triplett

Public Reading Room

P7 -82

K7 -97

K7 -90

Technical Files

A1 -65

$\mathrm{K} 1-11$

1

ICF Kaiser Hanford

R. H. Beers

B4-52

V. R. Weil

2

BCS Richland, Inc.

T. 0 . Elsethagen

A2-50

D. T. Romine

H4-80

1

Hanford Environmental

Health Foundation

R. H. Ronish

H1 - 75

1

MAC Technical Services Company

W. M. Ritter

A4-35

Distr-2 